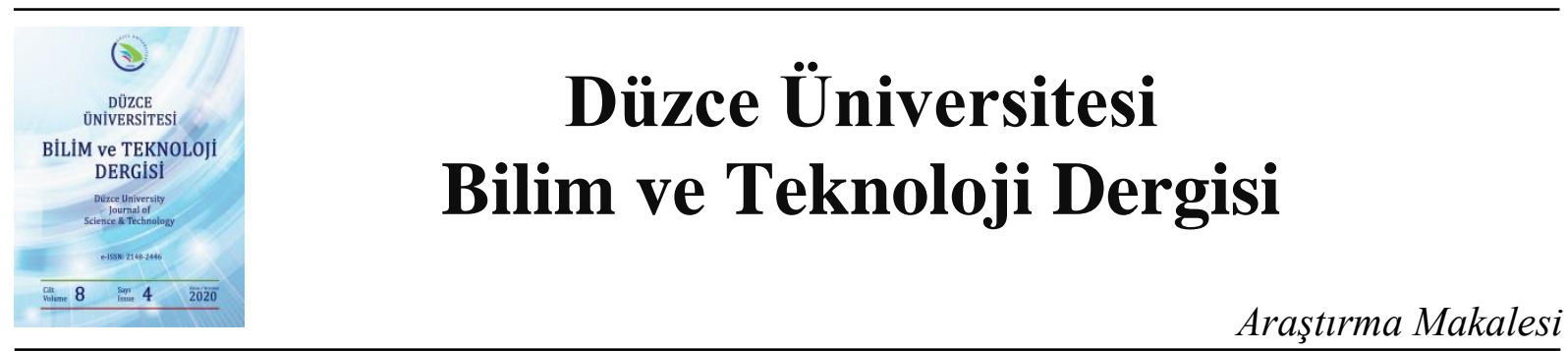

\section{Polikristal Tür bir Fotovoltaik Panelin I-V Karakteristiğinin Analitik Modellenmesi ve Deneysel Doğrulanması}

\author{
Ali Naci Çelik ${ }^{\mathrm{b}, *}$, (D) Fatih Koç ${ }^{\mathrm{a}}$ \\ ${ }^{a}$ Karaköy Mahallesi Çayır Sokak, No:6, Daire:8, BAİBU Kampüsü, Bolu, TÜRKİYE \\ ${ }^{b}$ Makine Mühendisliği Bölümü, Mühendislik Fakültesi, Bolu Abant İzzet Baysal Üniversitesi, Bolu, TÜRKIYYE \\ * Sorumlu yazarın e-posta adresi: celikan@ibu.edu.tr \\ DOI: 10.29130/dubited.789691
}

\begin{abstract}
ÖZET
Fotovoltaik hücreler, güneşten gelen elektromanyetik enerjiyi elektrik enerjisine dönüştüren enerji dönüşüm sistemleridir. Bu çalışmada 4042'52.2”K, 31³1'29.8”'D koordinatlarında kurulu bulunan 36 hücreli polikristal tür bir güneş paneli, çeşitli sensörler ve veri kaydedici cihazlar kullanılarak hazırlanan deney düzeneği temelinde; i) güneş 1şınım şiddetinin fotovoltaik panel üzerindeki etkisinin incelenmesi, ii) fotovoltaik panelin akım-voltaj (I-V) karakteristiğinin incelenmesi, iii) fotovoltaik panelden elde edilen akım-voltaj eğrilerinin literatürdeki modeller ile karşılaştırılması ve doğrulanması amaçlanmıştır. Söz konusu fotovoltaik panel için farklı güneş 1şınım şiddetinde ve farklı sıcaklıklarda ölçülen I-V karakteristikleri; 4-değişkenli, 5-değişkenli, geliştirilmiş 4-değişkenli ve 2-diyotlu model olmak üzere toplam 4 farklı analitik model kullanılarak modellenmiş ve doğrulanmıştır. I-V ilişkisini tanımlayan analitik denklemler Visual Basic programlama dili kullanılarak çözümlenmiştir. Modellerden elde edilen sonuçlar ile ölçülen değerler arasındaki karşılaştırma $R^{2}$ ve $R M S E$ olmak üzere 2 istatistiksel parametre üzerinden gerçekleştirilmiştir. Farklı 1şınım değerleri ve sıcaklıklar için modellerden elde edilen sonuçlar ile ölçüm değerleri karşılaştırıldığında $R^{2}$ değerlerinin \% 055,86 ile \%09,86 arasında, RMSE değerlerinin ise 0,093 ile 0,861 değiştiği gözlenmektedir. Elde edilen sonuçların istatistiksel analizi; bu çalışma kapsamında kullanılan 4 farklı model içerisinde, geliştirilmiş 4-değişkenli modelin diğer modellere göre daha başarılı tahmin sonuçlarına yol açtığını göstermektedir.
\end{abstract}

Anahtar Kelimeler: Fotovoltaik Hücre, Fotovoltaik I-V Ĕgrisi, 2-diyotlu Model

\section{Analytical Modelling and Experimental Validation of the I-V Characteristics of a Polycrystalline Type of Photovoltaic Panel}

\begin{abstract}
Photovoltaic cells are energy conversion systems that convert the electromagnetic energy coming from the sun to electrical energy. In this study, based on an experimental facility, incorporating a polycrystalline photovoltaic panel made up of 36 cells, various sensors and a data logger device, located at the coordinates of $40^{\circ} 42^{\prime} 52.2^{\prime \prime} \mathrm{N}$, $31^{\circ} 31^{\prime} 29.8^{\prime \prime} \mathrm{E}$, the followings are aimed; i) investigation of the effect of solar radiation intensity on the photovoltaic panel, ii) investigation of the current-voltage characteristics of the photovoltaic panel, and iii) comparison of the current-voltage curves measured from the photovoltaic panel with those obtained from the models available in the literature and thus validation. The current-voltage characteristics of the photovoltaic panel measured at different solar radiation and temperature levels have presently been modelled and validated
\end{abstract}


using a total of 4 different analytical models namely, 4-parameter, 5-parameter, improved 4-parameter and 2diode models. The equations defining the current-voltage relationship have been solved using Visual Basic programming language. The comparison between the results obtained from the solutions of the models and those measured has been made based on the statistical parameters of $R^{2}$ and RMSE. When the results obtained from the models and the measurements for various solar radiation and temperature values are compared, it is seen that $R^{2}$ values vary from $\% 95,86$ to $\% 99,86$ and the $R M S E$ values from 0,093 to 0,861 . The statistical analysis of the results obtained has shown that amongst the 4 different models used in the present thesis, the improved 4parameter model leads to better estimation results than the other models used.

Keywords: Photovoltaic Cell, Photovoltaic I-V curve, 2-diode model

\section{GIRIS}

Dünya üzerindeki enerji kaynakları farklı şekillerde sınıflandırılabilir. Doğada arz bağlamında sürekliliklerine/tükenebilirliklerine göre sınıflandırılan enerji kaynakları; yenilenebilir ve yenilenemez enerji kaynakları olarak ikiye ayrılır. Bunlardan fosil esaslı kaynaklar gibi yenilenemez olan enerji kaynakları kullanıldığında doğa tarafından yeniden üretilmediği için zamanla tükenirken güneş enerjisi gibi yenilenebilir enerji kaynakları ise doğada süreklilik arz ederler. Doğada bulunabilirliklerine göre sınıflandırdığımız enerji kaynakları; birincil ve ikincil enerji kaynakları olarak ikiye ayrılır. Birincil enerji kaynakları doğadan doğrudan elde edilirken ikincil enerji kaynakları ise doğadan doğrudan elde edilemeyen, birincil enerji kaynaklarından dönüştürülen enerji kaynaklarını ifade etmektedir.

Dünya üzerinde bilinen fosil enerji rezervlerine bakıldığında; günümüzdeki kullanım hızına göre petrolde 54 yıl, doğalgazda 64 yıl, kömürde 112 yıl yetecek düzeyde rezerv bulunduğu tahmin edilmektedir [1]. Tüketimde ise, 2018 yılı verilerine bakıldığında dünya üzerinde toplam birincil enerji kullanımının 13,865 milyon ton petrol eşdeğeri olduğu görülmektedir. Bu tüketimde en büyük paya sahip olan birincil enerji kaynağı \%33,6 ile petroldür. \%27,2 ile kömür ve \%23,9 oran ile doğalgaz dünya üzerinde tüketilen enerji kaynakları içerisinde büyük bir paya sahiptir [2]. Bu fosil esaslı kaynakları \%9,8 ile biyo yakıtlar ve atıklar, \%4,9 ile nükleer, \%2,5 ile hidrolik ve \%1,7 ile yenilenebilir enerji kaynakları (rüzgâr, güneş, jeotermal vb.) izlemektedir [2]. Dünya üzerindeki kurulu güce bakıldığında ise elektrik enerjisinin \%41'inin kömür, \%21'inin doğalgaz, \%16'sının hidroelektrik, \%14'ünün nükleer, \%6'sının petrol ve \%2'sinin de yenilenebilir esaslı santrallerden üretildiği görülmektedir [2].

Gelişmekte olan bir ülke olan Türkiye'de artan nüfus ve gelişen teknolojiler ile enerji ihtiyacı da zamanla artmaktadır. Türkiye, ihtiyacı olan bu enerjiyi düşük kaliteli olmasına rağmen linyit, taşkömürü, petrol, doğalgaz gibi fosil kaynaklardan ve hidroelektrik, biyokütle, jeotermal, rüzgâr ve güneş enerjisi gibi yenilenebilir kaynaklardan sağlamaktadır. Gelişen sanayi ve ilerleyen teknolojiyle birlikte Türkiye, enerji ihtiyacını karşılamak için çeşitli enerji kaynakları arayışlarına girmiş ve yatırımlar yaparak kurulu gücünü hızlı bir şekilde arttırmıştır. 2016 yılı sonu verilerine göre Türkiye'nin toplam kurulu gücü yaklaşık olarak 88569 MW kapasiteye ulaşmıştır. 2018 y1lı verilerine göre, üretilen elektrik enerjisi miktarı 303625 GWh olarak gerçekleşmiştir [3]. 2018 yılı sonu itibarı ile dünyada kurulu fotovoltaik gücü 480,4 GW'a, üretilen elektrik enerjisinin toplamı ise 443,6 TWh'a ulaşmıştır [2]. Çin toplamda $175 \mathrm{GW}$ kurulu güç ile ülke sıralamasında ilk sıradadır. Türkiye'nin 2018 yılı sonu itibarı ile kurulu fotovoltaik gücü 5065 MW'a, üretilen elektrik enerjisinin toplamı ise 7477 GWh'a ulaşmıştır [3]. 
Dünya üzerinde $36^{\circ}-42^{\circ}$ kuzey enlemleri ile $26^{\circ}-45^{\circ}$ doğu boylamları arasında yer alan Türkiye, birçok ülkeye göre güneş enerjisi potansiyeli açısından şanslı bir konumda yer almaktadır. Devlet Meteoroloji İşleri Genel Müdürlüğü'nün yaptığı çalışmalardan yola çıkılarak, Elektrik İşleri Etüt İdaresi'nin yaptığı çalışmalar Türkiye'de ortalama yıllık toplam güneşlenme süresinin 2640 saat olduğunu göstermektedir. Türkiye'nin coğrafi bölgelerine bakıldığında, en uzun güneşlenme süresinin Güneydoğu Anadolu ile Akdeniz Bölgeleri'nde olduğu görülmektedir. Türkiye üzerine düşen ortalama toplam y1llık güneş enerjisi ise $1303 \mathrm{kWh} / \mathrm{m}^{2}$ olarak tespit edilmiştir [4]. Türkiye üzerine düşen y1llık toplam güneş enerjisinin Güneydoğu Anadolu Bölgesi, Akdeniz Bölgesi ve Ege Bölgesinin güney kesimlerinde oldukça yüksek olduğu görülmektedir. Türkiye'nin kuzey kesimlerine düşen 1şınım miktarının düşük olması nedeniyle, Karadeniz Bölgesi'nin potansiyelinin göreceli olarak düşük olduğu değerlendirilebilir. Onun dışında kalan bölgelere baktığımızda yıllık ortalama güneş enerjisi potansiyelinin en az $1100 \mathrm{kWh} / \mathrm{m}^{2}$ olduğu görülmektedir [4].

Fotovoltaik hücreler, güneşten gelen elektromanyetik enerjiyi elektrik enerjisine dönüştüren enerji dönüşüm sistemleridir. Bu çalışma ile 4042’52.2”K, 31³1'29.8”D koordinatlarında kurulu bulunan 36 hücreli polikristal tür bir güneş paneli, çeşitli sensörler ve veri kaydedici cihazlar kullanılarak hazırlanan deney düzeneği temelinde; i) güneş 1şınım şiddetinin fotovoltaik panel üzerindeki etkisinin incelenmesi, ii) fotovoltaik panelin akım-voltaj (I-V) karakteristiğinin incelenmesi, iii) fotovoltaik panelden elde edilen akım-voltaj eğrilerinin literatürdeki modeller ile karşılaştırılması ve doğrulanması amaçlanmıştır. Söz konusu fotovoltaik panel için farklı güneş 1şınım şiddetinde ve farklı sıcaklıklarda ölçülen I-V karakteristikleri; 4-değişkenli, 5-değişkenli, geliştirilmiş 4-değişkenli ve 2-diyotlu model olmak üzere toplam 4 farklı analitik model kullanılarak modellenmiş ve doğrulanmıştır. I-V ilişkisini tanımlayan analitik denklemler Visual Basic programlama dili kullanılarak çözümlenmiştir.

\section{FOTOVOLTAİK HÜCRELER VE ENERJI DÖNÜSÜMÜ}

Farklı iki tip yarı iletken yapının birleştirilmesi ile bir elektriksel alan oluşturulması esasına dayalı bir yap1 olan fotovoltaik hücreler, üzerlerine düssen fotonun taşıdı̆̆ enerjinin elektron tarafından yutulması neticesinde elektrik akımı üreten enerji dönüşüm araçlarıdır.

Yarı iletken malzemeler arasında en elverişli olanlar, silisyum, galyum arsenit, kadmiyum tellür gibi maddelerdir [5]. Bu yarı iletken malzemelerden elektrik akımı elde etmek için döküm kristalin içerisine başka malzemenin atomları eklenerek p-tipi veya n-tipi yarı iletken yapılar elde edilir [6]. Örnek olarak, silisyumun atom numarası 14'tür ve valans bandındaki değerlik elektron sayısı 4'tür. Eriyik haldeki silisyum içerisine kontrollü bir şekilde periyodik tablonun 5A grubu elementlerinden bir tanesini eklediğimizde değerlilik elektron sayısı 5 olduğundan, atomun dişarda kalan 1 elektronu yapıya verilir. Bu şekilde, $\mathrm{n}$-tipi bir yarı iletken malzeme elde edilmiş olur. Benzer bir şekilde, eriyik haldeki silisyum içerisine 3A grubu elementlerinden birini eklediğimizde, değerlilik elektron sayısı 3 olduğu için silisyumla reaksiyona girdiğinde 1 elektron eksik kalmaktadır. Bu eksik kalan elektron yerlerine de boşluk adı verilmektedir. Bu şekilde, p-tipi bir yarı iletken malzeme elde edilmiş olur [7]. Elde edilen bu n-tipi ve p-tipi plakalar bir araya getirilmek suretiyle fotovoltaik hücreler elde edilir (Şekil 1). N-tipi plakanın üzerine düşen güneş 1şığı, plakada fazladan bulunan 1 elektrona gereken enerjiyi verdiğinde elektron p-tipi plakaya sıçrama yapar. Bunu yaparken de devrede doğru akım meydana gelir. 


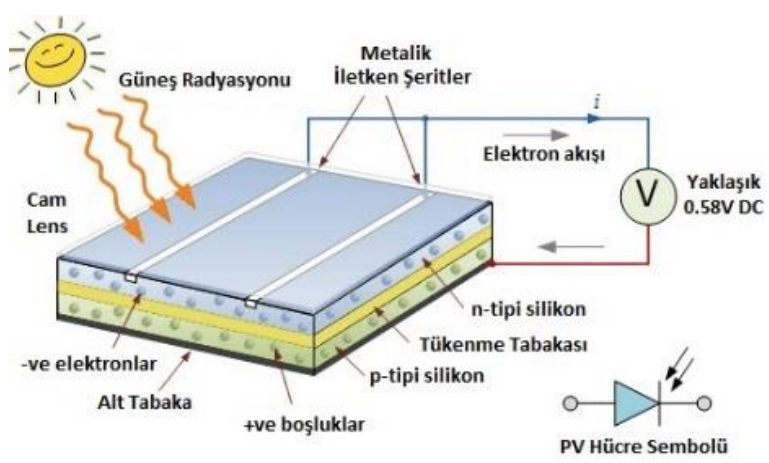

Şekil 1. Fotovoltaik Hücrenin Basit Yapısı [7]

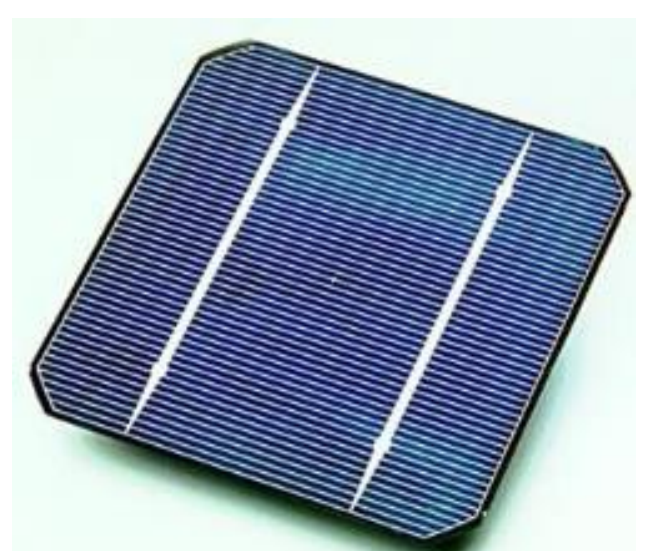

Şekil 2. Bir Fotovoltaik Hücre [3]

Silisyum esaslı fotovoltaik hücreler, yarı iletken olan silisyumun üzerine, iletken çubukların ve onlardan daha ince olan parmakların plakaya basılmasıyla elde edilir (Şekil 2). Üretilen bu hücrelerin gücü devreden geçen akımla orantılı olarak değişmektedir. Bu akımı arttırabilmek için fotovoltaik yapıdaki elektron ve boşluk sayılarını arttırmak gerekir. $\mathrm{Bu}$ da yüzey alanın arttırılmasıyla gerçekleşmektedir. Üretilen hücreler birbirlerine lehimlerle bağlanarak fotovoltaik modüller, modüller birbirlerine bağlanarak paneller, panellerde birbirlerine bağlanarak fotovoltaik diziler elde edilir (Şekil 3). Böylece, elde edilen güç arttırılmış olur.

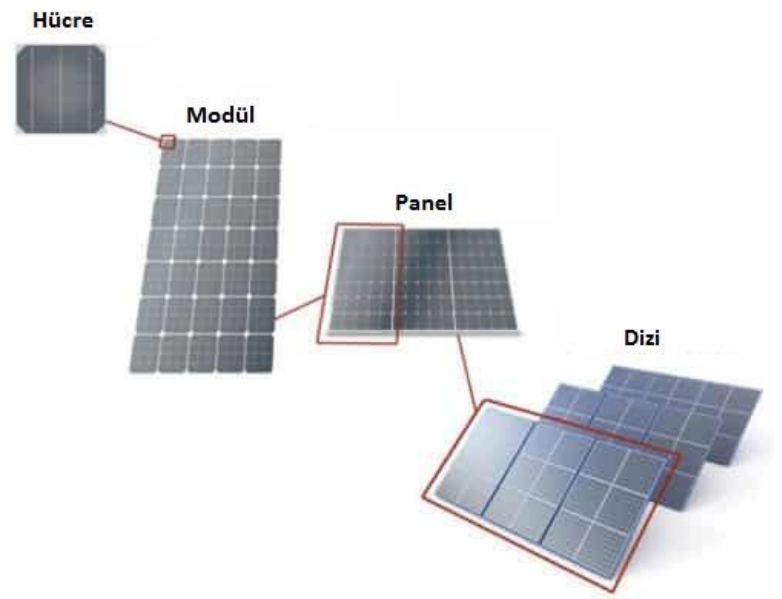

Şekil 3. Fotovoltaik Hücrelerin Bağlanması [7] 
Meydana gelen bu akım bataryada depolanabilir, sistemde doğru akım olarak kullanılabilir veya invertör yardımı ile alternatif akıma çevrilerek alternatif akım sistemlerinde kullanılabilir (Şekil 4).

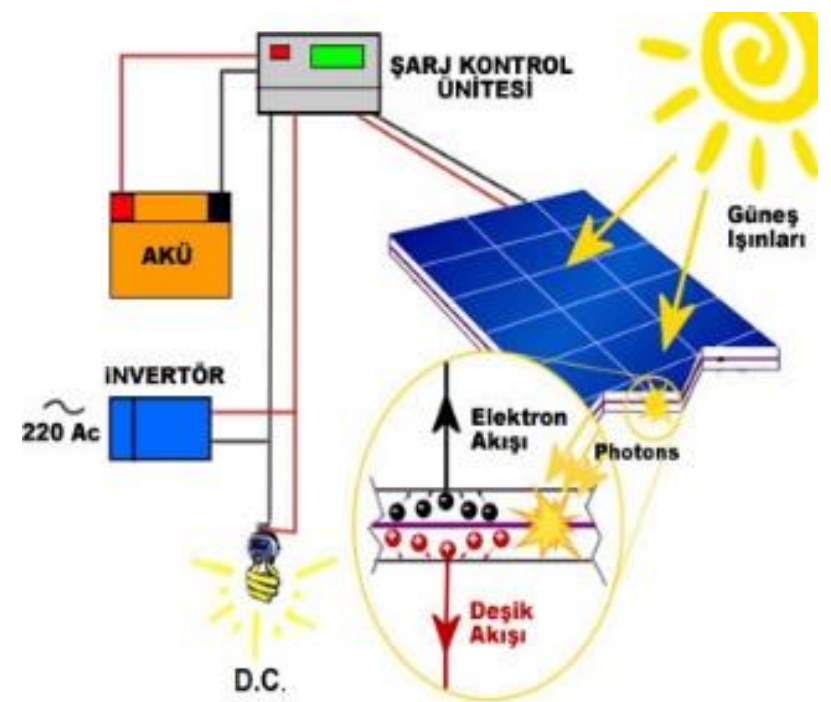

Şekil 4. Fotovoltaik Hücrelerin Sistemde Kullanılması [7]

\section{A. FOTOVOLTAIKK HÜCRELERİ ÇEŞITLERİ}

Fotovoltaik hücrelerin üretiminde hammadde olarak genellikle doğada bol miktarda bulunan silisyum kullanılır. Elde edilen bu hücreler üretim yöntemlerine göre farklı isimlerle adlandırılırlar.

\section{A. 1. Birinci Jenerasyon Fotovoltaik Hücreler}

$\mathrm{Bu}$ tür fotovoltaik hücrelerde hammadde olarak yüksek saflıkta silisyum kristalleri kullanılır. Monokristal ve polikristal fotovoltaik hücreler olarak iki ana başlık altında toplanabilir. İleri teknoloji gerektiren bir üretimdir. Verimleri diğer yöntemlerle üretilen hücrelere göre daha yüksek ve ömürleri daha uzundur. Monokristal fotovoltaik hücrelerin kristal yapıları düzenlidir. Bu yüzden üretimi zor ve maliyeti yüksektir. Polikristal fotovoltaik hücrelerde ise kristal yapısındaki çok az miktarda olan bozukluklar bu tip hücrelerin verimlerinin bir miktar düşmesine sebep olmaktadır. Ancak monokristal fotovoltaik hücrelere kıyasla üretimindeki kolaylık ve maliyetinin düşük olması tasarımlarda bu tip hücrelere yönelimin artmasına neden olmaktadır.

\section{A. 2. İkinci Jenerasyon Fotovoltaik Hücreler}

İnce film güneş hücreleri diye adlandırılan bu fotovoltaik hücreler daha çok çatı uygulamaları için imal edilmiştir. Esnek yapıda üretildikleri için bazı tasarımlar bükülebilirler. Diğer hücrelere göre üstünlügü, kolay taşınabilir ve kurulabilir olmasıdır. Ancak verimleri düşüktür. İnce film fotovoltaik hücrelerde, 1şığın daha geniş bant aralığında faydalanıldığ i için kapalı havalarda birinci jenerasyonlara göre verimleri bir miktar daha yüksektir. Bu tip bazı hücreler kızıl ötesi ışık altında bile elektrik akımı verebilmektedir.

\section{A. 3. Üçüncü Jenerasyon Fotovoltaik Hücreler}

Organik fotovoltaik hücre olarak adlandırılan üçüncü jenerasyon fotovoltaik hücrelerde amaç hücrenin üst yüzeyini aktif polimer tabaka ile kaplayarak, güneşten gelen ışığın hücre üzerindeki katmanda mümkün olduğunca fazla absorbe edilmesini amaçlamaktır [8]. Birkaç katman kullanılarak üretilen bu 
hücrelerde optik geçirgenlik ve maksimum verimin sağlanabilmesi için bütün katmanların kristal yapıları birbiriyle uyumlu olmalıdır.

\section{B. FOTOVOLTAİK HÜCRELERİN GELIŞSIM SÜREÇLERİ VE VERIMLILIKILERİ}

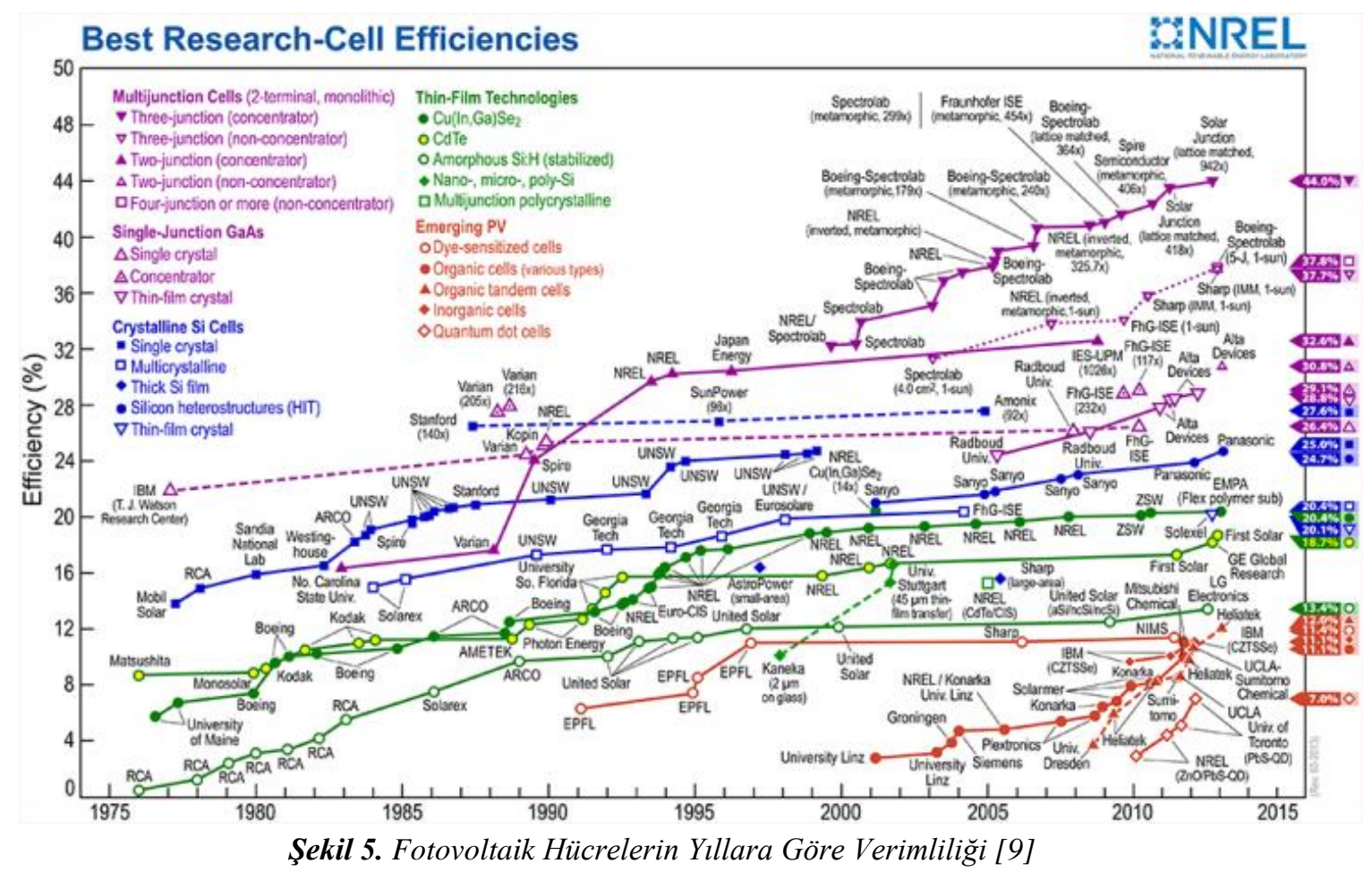

1836 y1lında Alexander Edmond Becquerel'in platin tabakalar üzerinde deneyler sirasında fotovoltaik etkiyi gözlemlemesinin ardından 1873 yılında Willoughby Smith selenyum içerisindeki fotoiletkenliği keşfederek ilk düzeneği oluşturdu. 1883 yılına ise Charles Fritts'in selenyum kullanarak geliştirdiği fotovoltaik hücrelerin verimleri \%1 olarak hesaplandı. 1954 y1lında ise gelişen teknoloji ile birlikte Bell Laboratuvarında üretilen silisyum fotovoltaik hücrelerin verimleri \%6 seviyesine ulaştı. 1957 yılında, Hoffman Elektronik isimli firma silisyum fotovoltaik hücreleri geliştirerek verimlerini $\% 8$ değerine çıkarmayı başardı. Aynı firma, bir sene sonra hücreleri daha da geliştirerek verimi \%9 seviyesine taşıd. Fotovoltaik hücrelerdeki bu gelişim hücrelerin güvenilir bir enerji kaynağı olarak görülmesini sağladı ve aynı yıl uzay biliminde ilerleyen birkaç yıl içinde de havacılık biliminde kullanılmaya başlandı. 1960 yılında aynı firma, \%14 verimde silisyum fotovoltaik hücre geliştirdi. 1970'li yılların sonuna doğru dünyada ortaya çıkan enerji krizi fotovoltaik hücreler üzerinde yapılan araştırma ve geliştirmelerin artmasını sağladı. 1985 yılında New South Wales Üniversitesinde yapılan araştırmalarda verimliliği \%20 olan silisyum fotovoltaik hücreler üretildi. 2000, 2002 ve 2005 yıllarında sırasıyla $\% 20, \% 26$ ve $\% 28$ verimliliğinde üç eklemli hücreler üretildi. 2006 yılında Spectrolab isimli şirket üç eklemli hücreler üzerinde yaptığı geliştirmelerle verimliliği \% 40 düzeyine çıkarmayı başardı. 2008 yılında ise Ulusal Yenilenebilir Enerji Laboratuvarında (NREL) yapılan çalışmalar sonucunda üretilen üç eklemli hücrelerin verimliliğinin $\% 40,8$ olarak açılamasıyla, fotovoltaik hücrelerin verimliliği alanında yeni bir dünya rekoru kırılmış oldu. Ancak, bu çok fazla sürmedi. 2009 yılında Spectrolab şirketinin çalışmaları sonucunda üç eklemli fotovoltaik hücrelerde verim \%41,6 seviyesine yükseldi ve bu alandaki rekorun yeniden sahibi oldu. Fotovoltaik hücrelerin yıllara göre verimliliği Şekil 5'te görülmektedir [9]. 


\section{FOTOVOLTAİK HÜCRELERIN MODELLENMESİ}

Fotovoltaik sistemlerin performans ve verimliliklerinin tahmin edilmesi ve güç dönüştürücü ile fotovoltaik diziler arasındaki etkileşimin incelenmesi için hızlı ve güvenilir bir simülatör fotovoltaik sistem tasarımı için vazgeçilmez bir unsurdur [10]. Bu doğrultuda, fotovoltaik sistemler için kullanılan simülatörlerin en önemli bileşenlerini ise fotovoltaik hücrenin çalışma koşullarında ölçülen I-V eğrisine uyum sağlayan fotovoltaik hücre modeli oluşturmaktadır. Fotovoltaik modelleme ve parametre tahminlerine ilişkin bilimsel yayınlar oldukça fazladır ve dergi, konferans, sınıflandırılmış ve sınıflandırılmamış birçok belgede görmek mümkündür. Yıllar boyunca temel diyot modelinden başlayarak, $R_{S}$ modelleme, $R_{S h}$ modelleme ve iki ve üç diyotlu modellemeye kadar birçok farklı model önerilmiştir $[11,12]$.

Günümüzde en çok kullanılan, doğrusal ve doğrusal olmayan bileşenlerden oluşan modelleme yaklaşımı olan eşdeğer elektrik devresi ve onun matematiksel modeli sırası ile Şekil 6 ve Denklem (1)'de verilmektedir [13]. Eşdeğer elektrik devresi modelinin kullanılmasının başlıca avantajı, Matlab, PSpice, Visual Basic, C gibi programlama dillerinde kullanılabilirliğidir. Eşdeğer elektrik devresini kullanmayan farklı fotovoltaik modelleme teknikleri de vardır [14, 15]. Ancak, bu modelleme yöntemleri fotovoltaik simülatörleri tarafından benimsenmemiştir.

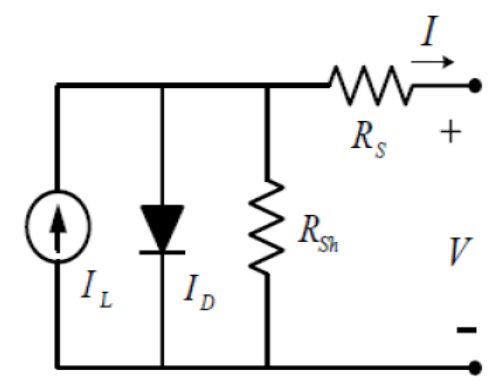

Şekil 6. Basitleştirilmiş Eşdeğer Fotovoltaik Hücre Devresi

Şekil 6'da gösterilen devre şemasında eşdeğer fotovoltaik hücre devresi, bir akım kaynağı, akım kaynağına paralel olarak bağlanmış bir diyot ve seri olarak bağlanmış bir direnç olarak sembolize edilmiştir. Güneş ışınımının yokluğunda, hücre basit bir p-n bağlantılı diyot gibi davranır. Diyot akımı, literatürde iyi bilinen ve diyot akımını ifade eden Shockey denklemleriyle tanımlanmaktadır [16]. Bu eşdeğer fotovoltaik hücre devresi matematiksel olarak aşağıdaki denklem ile ifade edilebilir [17].

$I=I_{L}-I_{D}=I_{L}-I_{0}\left[\exp \left(\frac{V+I R_{S}}{\alpha}\right)-1\right]-\frac{V+I R_{S}}{R_{S h}}$

$I=$ Yük Akımı (A)

$I_{L}=$ Işı $\mathrm{k}$ Akımı (A)

$I_{0}=$ Ters Doyma Akımı (A)

$V=$ Gerilim $(\mathrm{V})$

$R_{S}=$ Seri Direnç $(\Omega)$

$R_{\text {sh }}=$ Paralel Direnç $(\Omega)$

$\alpha=$ Modifiye Edilmiş Diyot İdealite Faktörü (V)

Fotovoltaik hücrelerde, yukarıdaki denklemde belirtilen diyot ters doyma akımı $\left(I_{0}\right)$, diyotun mutlak sıcaklığı, diyotun gerilimi ve yük tarafından çekilen akımın fonksiyonu olarak değişkenlik gösterir 
[18]. Yukarıdaki denklem içerisinde yer alan modifiye edilmiş diyot idealite faktörü $(\alpha)$ ise, mutlak sıcaklık ve diyot idealite faktörüne göre değişkenlik göstermektedir.

$\alpha=\frac{n k T N_{S}}{q}$

Yukarıdaki denklemde belirtilen modifiye edilmiş diyot idealite faktörünü hesaplarken, $n$ diyot idealite faktörünü sembolize etmektedir. Bu parametre ideal diyotlarda 1 olarak kabul edilirken gerçek tipik diyotlarda ise 1 ve 2 arasında kabul edilir. $k$ ile sembolize edilen Boltzmann sabitidir ve değeri $1,381 \times 10^{-23} \mathrm{~J} / \mathrm{K}$ 'dir. $T$ mutlak sicaklı̆̆ 1 ifade eder ve birimi kelvin'dir. $N_{S}$ panel üzerinde bulunan seri bağlı hücre sayısını ifade eder. $q$ ise elektron yükünü sembolize etmektedir ve değeri $1,602 \times 10^{-19}$ coloumb'dur.

En genel ifadesi ile fotovoltaik hücrelerin matematiksel modelleri, hücrenin akım ve gerilim değerleri arasındaki ilişkiyi hücre üzerine düşen ışınım şiddeti ve hücrenin yüzey sıcaklığı ile ilişkilendirmektir. Fotovoltaik modelleri kullanmak için devre parametrelerinin değerleri belirlenmelidir. Bunun için kullanılan en pratik yaklaşım panel üreticilerinin sunmuş olduğu veri sayfalarındaki bilgileri kullanarak bu değerleri tahmin etmektir. Denklemler, kısa devre akımı, açık devre gerilimi, maksimum güç noktasındaki akım ve gerilim değeri gibi temel noktalardan türetilerek oluşturulmuştur. Bununla birlikte seri ve paralel dirençleri hesaplamak için açık devre ve kısa devre koşullarında eğimlerin karşı1ıklı olarak kullanılması ve maksimum güç noktasındaki eğimin sıfıra eşit olduğu bilgisi doğrultusunda yeni denklemlerin türetilmesi için türev fonksiyonları da kullanılabilir $[19,20]$. Bazı durumlarda parametrelerin anlık olarak hesaplanması için açık devre sıcaklık katsayısı ve kısa devre sıcaklık katsayısı için analitik ifadeler kullanılır [21, 22]. Literatürde sıkça kullanılan yaklaşımlardan biriside sabit parametre kabulü ile yapılan modellemedir. Bu yöntemde, 1şık akımı ve ters doyma akımı çevre koşullarından etkilenirken, seri ve paralel dirençler belirlenmiş bir durum için sabit olarak kabul edilir. Bununla birlikte, fotovoltaik sistem fiziksel olarak 1şınım şiddeti ve sıcaklık değişikliklerine oldukça duyarlıdır.

Model parametrelerini elde etmek için alternatif bir yaklaşım da doğrusal olmayan optimizasyon teknikleri kullanarak I-V eğri uydurma yoluyla parametrelerin tespitidir. Fotovoltaik modellemede, model parametreleri ile ilgili kapsamlı bilgi gerektiğinde optimizasyon yaklaşımı kullanılır. Buradan elde edilen parametre değerlerinin doğruluğu algoritma tipine, amaç fonksiyonuna ve başlangıç koşullarına bağlıdır [23, 24]. İlk parametre değerinin uygun olmayan seçiminin uyumsuzluğa neden olabileceği kabul edilmektedir. Ayrıca parametre sayısı arttıkça yaklaşım doğru sonuçlar üretme yeteneğini kaybeder $[25,26]$.

Son yıllarda kayda değer potansiyellerinden dolayı, fotovoltaik modellemede kullanılan yaklaşımlardan birisi de yumuşak hesaplama yöntemleridir. Bunlardan bazıları genetik algoritma [27, 28], diferansiyel evrim [29, 30], parçacık sürüsü optimizasyonu [31, 32], benzetimli tavlama [26], guguk kuşu araştırması [33], bakteri yiyecek arama algoritması [34], armoni araması [35], desen arama optimizasyonu [36, 37], yapay arı sürüsü optimizasyonu [38] ve kuş çiftleşme düzenleyicisi [39] şeklinde gösterilebilir. Bu yaklaşımlar, küresel arama kabiliyetleri ve eğim bilgisi olmayan lineer olmayan fonksiyonların kullanımındaki etkinliği nedeniyle özellikle ilgi çekicidirler. Bu avantajlara rağmen, sayısal ve yakınsama hızında tutarlılı̆̆ garanti edemeyen, olasılıksal doğası nedeniyle fotovoltaik simülatörlerinde yumuşak hesaplama kullanımı genellikle tercih edilmemektedir. 


\section{A. MEVCUT ÇALIŞMADA KULLANILAN MODELLER}

Yukarıda ifade edildiği gibi fotovoltaik hücre teknolojileri ve bunların kullanım alanları hızlı bir gelişim göstermektedir. Bu gelişmelere paralel olarak fotovoltaik hücrelerin matematiksel modelleri üzerinde yapılan araştırmalar da hızla artmaktadır. Fotovoltaik hücrelerin I-V karakteristiği analitik ve nümerik yöntemler gibi farklı yaklaşımlar kullanılarak hesaplanabilir.

$\mathrm{Bu}$ çalışmada, yukarıda literatür özeti verilen yaklaşımlardan analitik yöntemler arasından seçilen 4 farklı model kullanılarak bir PV panelin I-V eğrisi elde edilmiş ve deneysel ölçüm sonuçları ile karşılaştırılmıştır. Söz konusu farklı modeller, analitik yöntemler arasında, içerisinde farklı sayıda parametre bulundurması bakımından potansiyel olarak literatürdeki mevcut modelleri yeterince temsil etmektedir. Bu bağlamda, bu çalışma kapsamında 4-değişkenli, 5-değişkenli, geliştirilmiş 4-değişkenli ve 2-diyotlu modeller olmak üzere toplam 4 faklı model kullanılarak bir fotovoltaik panelin elektriksel karakteristiği üzerine bir araştırma çalışması gerçekleştirilmiştir.

\section{A. 1. 4-Değişkenli Model}

Şekil 7'de verilen basit eşdeğer elektrik devresi benzetimi kullanılan bu modelin I-V eğri denklemi aşağıda verildiği gibidir [40]:

$I=I_{L}-I_{0}\left[\exp \left(\frac{V+I R_{S}}{\alpha}\right)-1\right]$

$\mathrm{Bu}$ fotovoltaik panelden elde edilen güç ise şu şekilde hesaplanabilir:

$P=I V$

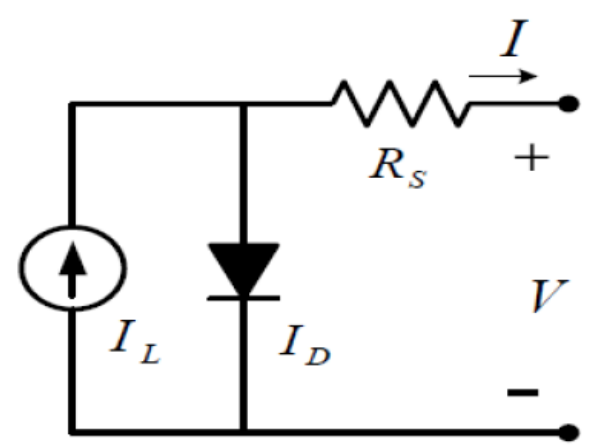

Şekil 7. 4-Değişkenli Model İ̧̧in Eşdeğer Elektrik Devresi

Yukarıdaki I-V denkleminin çözülmesi için öncelikle 4 değişkenin farklı 1şınım ve sıcaklık değerlerinde nasıl değiştiği bilgisine ihtiyaç duyulmaktadır. Bu 4 değişken $I_{L}, I_{0}, R_{S}$ ve $\alpha$ 'dır. $\mathrm{Bu}$ değişkenlerin denklemleri aşağıda verilmiştir:

$I_{L}=\left(\frac{G}{G_{r e f}}\right)\left[I_{L, r e f}+\mu_{I, s c}\left(T_{c}-T_{c, r e f}\right)\right]$

$I_{0}=I_{0, \text { ref }}\left(\frac{T_{c}}{T_{c, \text { ref }}}\right)^{3} \exp \left[\left(\frac{q N_{S}}{\alpha}\right)\left(1-\frac{T_{c, \text { ref }}}{T_{c}}\right)\right]$

$R_{S}=R_{S, r e f}$

$\alpha=\alpha_{r e f} \frac{T_{c}}{T_{c, r e f}}$ 
Yukarıda verilen denklemlerde görüldügü üzere, farklı koşullar ile birlikte değişiklik gösteren parametrelerin değerlerini hesaplamak için öncelikle söz konusu parametrenin referans koşullarına karşılık gelen değerinin hesaplanması gerekmektedir. Bu referans değerleri aşağıdaki denklemler kullanılarak hesaplanmaktadır:

$I_{L, r e f}=I_{s c, r e f}$

$\alpha_{\text {ref }}=\frac{\mu_{V, o c} T_{c, r e f}-V_{o c, r e f}+q N_{S}}{\frac{T_{c, r e f} \mu_{I, s c}}{I_{L, r e f}}-3}$

$I_{0, r e f}=\frac{I_{L, r e f}}{\exp \left(\frac{V_{o c, r e f}}{\alpha_{r e f}}\right)-1}$

$R_{s, r e f}=\frac{\alpha_{r e f} \ln \left(1-\frac{I_{m p, r e f}}{I_{L, r e f}}\right)-V_{m p, r e f}+V_{o c, r e f}}{I_{m p, r e f}}$

Parametrelerin referans değerleri hesaplanırken gerekli olan $\mu_{I, s c}$ ve $\mu_{V, o c}$ katsayıları kullanılan fotovoltaik panel için sırasıyla $0,001325 \mathrm{~A} / \mathrm{K}$ ve $-0,0775 \mathrm{~V} / \mathrm{K}$ olarak kabul edilmiştir. İhtiyaç duyulan değişkenler bu şekilde belirlendikten sonra fotovoltaik modülün I-V eğrisi Denklem (3)'te verildiği üzere hesaplanır. Bu şekilde elde edilen I-V eğrisi ile bu eğri üzerinde istenilen her noktaya karşılık gelen güç değeri Denklem (4) kullanılarak hesaplanabilir. Bununla birlikte, fotovoltaik hücrenin verebileceği maksimum güç değeri de hesaplanabilir. Belirlenen bu güç değeri yardımıyla fotovoltaik hücrenin verimini hesaplamak için:

$\eta=\frac{P}{G \times A} \times 100$

\section{A. 2. 5-Değişkenli Model}

Şekil 8'de 5-değişkenli bir fotovoltaik hücre için eşdeğer elektrik devresi verilmiştir. Görüldüğü üzere, 4-değişkenli modelden farklı olarak, 5-değişkenli eşdeğer elektrik devrede hücre içerisinde oluşan paralel devre dirençlerinin $\left(\boldsymbol{R}_{\boldsymbol{s}}\right)$ fotovoltaik hücrenin I-V karakteristiği üzerindeki etkisi de dikkate alınmaktadir.

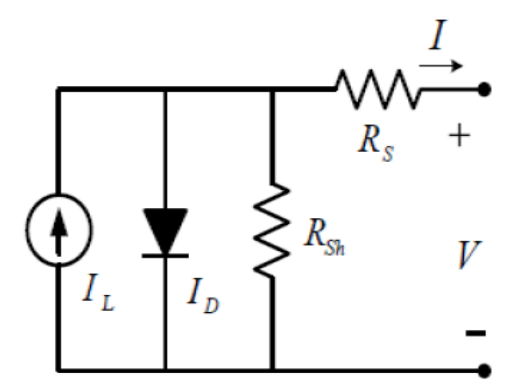

Şekil 8. 5-Değişsenli Model İ̧̧in Eşdeğer Elektrik Devresi

Ayrıca modifiye edilmiş diyot idealite faktörünün de $(\alpha)$ sıcaklığa bağlı olarak değiştiği bilinmektedir [40]. Bu model aşağıdaki denklem ile tanımlanmaktadır:

$I=I_{L}-I_{0}\left[\exp \left(\frac{V+I R_{S}}{\alpha}\right)-1\right]-\frac{V+I R_{S}}{R_{S h}}$

Denklem (14)'te gözüken modifiye edilmiş diyot idealite faktörü:

$\alpha=m V_{t}$

$m=$ idealite faktörü 
$V_{t}=$ termal gerilim $(\mathrm{V})$

Yukarıda belirtilen idealite faktörü ve termal gerilimi hesaplamak için aşağıda belirtilen denklemlerden yararlanabiliriz:

$$
\begin{aligned}
& V_{t}=\frac{k T_{c}}{q} \\
& m=n_{l} N_{s} \\
& \text { veya } \\
& m=\frac{V_{m p}+I_{m p} R_{s o}-V_{o c}}{V_{t}\left[\ln \left(I_{s c}-\frac{V_{m p}}{R_{S h}}-I_{m p}\right)-\ln \left(I_{s c}-\frac{V_{o c}}{R_{S h}}\right)+\left(\frac{I_{m p}}{\left.\left.I_{s c}-\frac{V_{o c}}{R_{S h}}\right)\right]}\right.\right.}
\end{aligned}
$$

Fotovoltaik hücre üzerinde oluşan ışık akımı $\left(I_{L}\right)$ ve ters doyma akımını $\left(I_{0}\right)$ hesaplamak için:

$I_{L}=I_{s c}\left(1+\frac{R_{s}}{R_{s h}}\right)+I_{0}\left[\exp \left(\frac{I_{s c} R_{S}}{m V_{t}}\right)-1\right]$

$I_{0}=\left(I_{s c}-\frac{V_{o c}}{R_{s h}}\right) \exp \left(-\frac{V_{o c}}{m V_{t}}\right)$

Fotovoltaik hücre üzerindeki dirençleri hesaplamak için:

$R_{S}=R_{s o}-\left[\frac{m V_{t}}{I_{0}} \exp \left(-\frac{V_{o c}}{m V_{t}}\right)\right]$

$R_{\text {sh }}=R_{\text {sho }}$

Hesaplanması gereken bu direnç değerleri üzerine tartışmalar devam etmektedir [41]. Konu ile ilgili yapılan literatür çalışması $R_{\text {so }}$ değerinin $0,30 \Omega$ ile $0,33 \Omega$ arasında $R_{\text {sho }}$ değerinin ise $50 \Omega$ ile $170 \Omega$ arasında değişkenlik gösterdiğini ortaya koymaktadır [40]. Diğer taraftan, fotovoltaik hücrelerin 1şınım şiddeti ve sıcaklığa bağlı olarak değişiklik gösteren kısa devre akımı $\left(I_{s c}\right)$ ve açık devre gerilimi $\left(V_{o c}\right)$ şu denklemler ile hesaplanmaktadır;

$I_{s c}=I_{s c, r e f} \frac{G}{G_{r e f}}+\mu_{I, s c}\left(T_{c}-\mathrm{T}_{c, r e f}\right)$
$V_{o c}=V_{o c, r e f}+m V_{t} \ln \left(\frac{G}{G_{r e f}}\right)+\mu_{V, o c}\left(T_{c}-T_{c, r e f}\right)$

Hesaplanan sonuçlardan sonra Denklem (14)'te 4-değişkenli modelde olduğu gibi her gerilim değeri için o gerilim değerine karşılık gelen akım değerinin hesaplanması gerekir. Hesaplanan gerilim ve akım değerleri yardımıyla fotovoltaik hücrenin seçilen değerdeki gücü hesaplanır ve fotovoltaik hücrenin çalışması gereken en verimli akım ve gerilim noktası tespit edilir. Fotovoltaik hücrenin verimini hesaplamak için Denklem (13) kullanılır. 


\section{A. 3. Geliştirilmiş 4-Değişkenli Model}

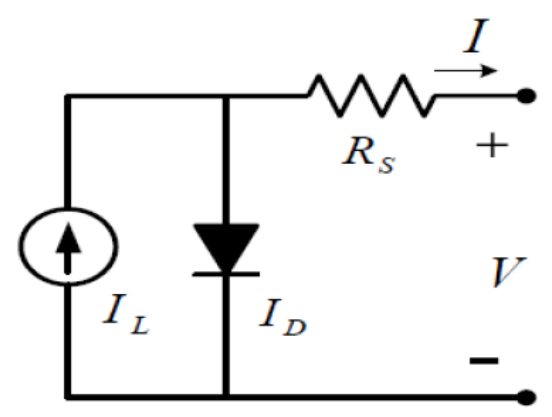

Şekil 9. Geliştirilmiş 4-Değişkenli Model İçin Eşdeğer Elektrik Devresi

Şekil 9'da fotovoltaik eşdeğer elektrik devresi verilen geliştirilmiş 4-değişkenli modelin amac1 4 parametreli modelde verilen referans değerlerini iyileştirerek hesaplanmak istenen sıcaklık ve 1şınım şiddetlerinde gerçeğe daha yakın sonuçlara ulaşmaktır [42]. Bu model için geçerli olan Denklem (25)'te belirtilmiştir.

$I=I_{L}-I_{0}\left[\exp \left(\frac{V+I R_{S}}{\alpha}\right)-1\right]$

Modelde kullanılacak olan hesaplanması gereken değişkenler olan $I_{L}, I_{0}, R_{S}$ ve $\alpha$ değerlerini bulabilmek için aşağıdaki denklemler çözülmelidir:

$I_{L}=I_{s c}$

$I_{0}=I_{s c}\left[\exp \left(-\frac{q}{N_{s} n k T_{c}} V_{o c}\right)\right]$

$I_{m}=I_{s c}\left[1-\exp \left(q \frac{V_{m}-V_{o c}+I_{m} R_{s}}{N_{s} n k T_{c}}\right)\right]$

$R_{S}=\frac{\frac{N_{s} n k T_{c}}{q} \ln \left(1-\frac{I_{m}}{I_{s c}}\right)+V_{o c}-V_{m}}{I_{m}}$

$\alpha=\frac{q\left(2 V_{m}-V_{o c}\right)}{N_{s} k T\left[\frac{I_{m}}{I_{S c}-I_{m}}+\ln \left(1-\frac{I_{m}}{I_{S c}}\right)\right]}$

Denklem (30) ile verilen modifiye edilmiş diyot idealite faktörü $(\alpha)$ ilk başta Nominal Operasyonel Hücre Sicaklığı (Nominal Operating Cell Temperature, NOCT) olarak adlandırılan referans koşullarındaki değerler kullanılarak hesaplanır. Bu koşullar genellikle panel üreticileri tarafindan veri sayfasında tüketicilere sunulmaktadır. Bu şekilde referans koşulları için hesaplanan parametreler aşağıda verilen denklemler ile referans koşullarından farklı sıcaklık ve 1şınım şiddeti altındaki değerlerinin hesaplanması için kullanılır [16, 43]:

$$
\begin{aligned}
& I_{s c}=I_{s c, \text { ref }} \frac{G}{G_{r e f}}+\mu_{I S c}\left(T_{c}-T_{c, \text { ref }}\right) \\
& V_{o c}=V_{o c, \text { ref }}+\frac{N_{s} n k T_{c}}{q} \ln \left(\frac{G}{G_{\text {ref }}}\right)+\mu_{V o c}\left(T_{c}-T_{c, \text { ref }}\right) \\
& I_{m}=I_{m, \text { ref }} \frac{G}{G_{\text {ref }}}+\mu_{I s c}\left(T_{c}-T_{c, \text { ref }}\right) \\
& V_{m}=V_{m, \text { ref }}+\frac{N_{s} n k T_{c}}{q} \ln \left(\frac{G}{G_{\text {ref }}}\right)+\mu_{V o c}\left(T_{c}-T_{c, \text { ref }}\right)
\end{aligned}
$$


Denklem (32) ve (33)'deki açık devre gerilimi $\left(V_{o c}\right)$ ve maksimum güç noktasındaki gerilim $\left(V_{m}\right)$ değerleri modellemenin gücünü geliştirebilmek için aşağıda verilen Denklem (35) ve (36) ile yeniden hesaplanır:

$$
\begin{aligned}
& V_{o c}=\frac{V_{o c, r e f}}{1+\beta_{1} \ln \left(\frac{G_{r e f}}{G}\right)}\left(\frac{T_{c, r e f}}{T_{c}}\right)^{\mathrm{V}_{1}} \\
& V_{m}=\frac{V_{m, r e f}}{1+\beta_{2} \ln \left(\frac{G_{r e f}}{G}\right)}\left(\frac{T_{c, r e f}}{T_{c}}\right)^{\mathrm{X}_{2}} \\
& \beta_{1}=\frac{\frac{V_{o c, r e f}}{V_{o c}^{1}}-1}{\ln \left(\frac{G_{r e f}}{G}\right)}, \quad \gamma_{1}=\frac{\ln \left(\frac{V_{o c, r e f}}{V_{o c}^{2}}\right)}{\ln \left(\frac{T_{c}}{T_{c, r e f}}\right)} \\
& \beta_{2}=\frac{\frac{V_{m, r e f}}{V_{m}^{1}}-1}{\ln \left(\frac{G_{r e f}}{G}\right)}, \quad \gamma_{2}=\frac{\ln \left(\frac{V_{m, r e f}}{V_{m}^{2}}\right)}{\ln \left(\frac{T_{c}}{T_{c, r e f}}\right)}
\end{aligned}
$$

Denklem (35) ve (36) $\beta_{1}, \beta_{2}, \gamma_{1}$ ve $\gamma_{2}$ fonksiyonlarını içermektedir. Bu denklemler içerisinde yer alan parametrelerin hangi koşullara denk geldiği Tablo 1'de açıklanmaktadır.

Tablo 1. $\boldsymbol{\beta}_{1}, \boldsymbol{\beta}_{2}, \gamma_{1}$ ve $\mathrm{\gamma}_{2}$ parametrelerinin denk geldiği koşullar

\begin{tabular}{|c|c|c|}
\hline & $G_{\text {ref }}$ & $G$ \\
\hline$T_{c, \text { ref }}$ & $V_{o c, r e f}, V_{m, r e f}$ & $V_{o c}^{1}, V_{m}^{1}$ \\
\hline$T_{c}$ & $V_{o c}^{2}, V_{m}^{2}$ & \\
\hline
\end{tabular}

Tablo 1'de belirtilen açık devre gerilim noktaları $\left(V_{o c, r e f}, V_{o c}^{1}, V_{o c}^{2}\right)$ ve maksimum güç noktasındaki gerilim değerleri $\left(V_{m}, V_{m}^{1}, V_{m}^{2}\right)$ için tabloda bu değerlere karşılık gelen 1şınım şiddeti ve sıcaklık değerleri ile birlikte Denklem (32) ve Denklem (33) kullanılarak ayrı ayrı hesaplama yapılır. Yeni hesaplanan açık devre gerilimi ve maksimum güç noktasındaki gerilim değerleri kullanılarak; Denklem (27)'de belirtilen ters doyma akımı $\left(I_{0}\right),(28)$ 'de maksimum güç noktasındaki akım $\left(I_{m}\right)$, (29)'da seri devre direnci $\left(R_{S}\right)$ ve (30)'da modifiye edilmiş diyot idealite faktörü $(\alpha)$ yeniden hesaplanır. Bu hesaplanan değerler Denklem (25)'te kullanılarak söz konusu koşullarda I-V eğrisi elde edilir. Gerilim ve o gerilime karşılık gelen akım değerleri bulunduktan sonra Denklem (4) kullanılarak fotovoltaik hücrenin çalışması gereken maksimum güç değeri hesaplanır. Maksimum verimde çalışan fotovoltaik hücrenin verimi Denklem (13) ile hesaplanır.

\section{A. 4. 2-Diyotlu Model}

2-diyotlu model için kullanılacak fotovoltaik eşdeğer devresi Şekil 10'da gösterilmiştir [44]. Önceki modellerde yapılan hesaplamalar, tükenme bölgesinde meydana gelen kayıpların ihmal edilebilir olduğu varsayımına dayanmaktadır. Ancak, gerçekte bu bölgede de ihmal edilemeyecek seviyede kayıplar yaşanmaktadır. 2-diyotlu model yaklaşımı, bu kayıpların da hesaplanması gerektiği düşüncesini içermektedir. 


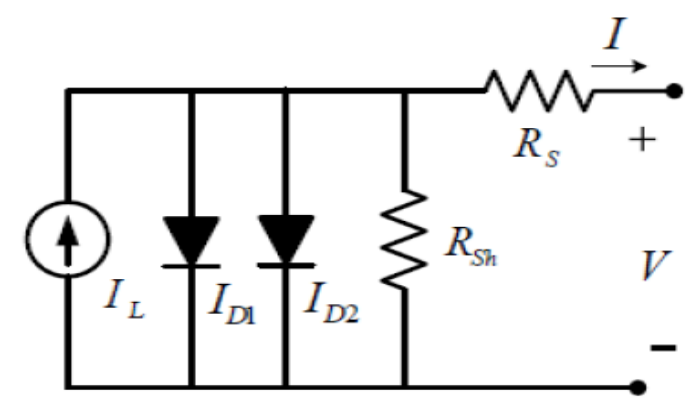

Şekil 10. 2-Diyotlu Model İ̧̧in Eşdeğer Elektrik Devresi

Bu model için şu denklem ile verilmektedir:

$I=I_{L}-I_{01}\left[\exp \left(q \frac{V+I R_{S}}{n_{1} k T_{c} N_{S}}\right)-1\right]-I_{02}\left[\exp \left(q \frac{V+I R_{S}}{n_{2} k T_{c} N_{S}}\right)-1\right]-\left(\frac{V+I R_{S}}{R_{S h}}\right)$

Denklem (37)'de kullanılan diyot faktörleri $n_{1}$ ve $n_{2}$ farklı şekilde türetilerek hesaplama yapılabilir. Ancak bu değerler belirlenirken söz konusu sınır koşulları şunlardır: $n_{1} \geq 1, n_{2} \geq 1$ ve $p \geq 2,2$. Bu değerleri belirlemek için kullanılması gereken Denklem (40) ile verilmiştir.

$\frac{n_{1}+n_{2}}{p} \geq 1$

Denklem (39)'daki diğer parametreler aşağıda verilen denklemler ile hesaplanır:

$$
\begin{aligned}
& I_{L}=\left[I_{L, r e f}+\mu_{I s c}\left(T_{C}-T_{c, r e f}\right)\right]\left(\frac{G}{G_{r e f}}\right) \\
& I_{L, r e f}=I_{s c, r e f} \\
& I_{01}=I_{02}=\frac{I_{s c, r e f}+\mu_{I s c}\left(T_{c}-T_{c, r e f}\right)}{\exp \left[\frac{q\left(V_{o c, r e f}+\mu_{V o c}\left(T_{c}-T_{c, r e f}\right)\right)}{N_{S} k T_{c}\left(\frac{n_{1}+n_{2}}{p}\right)}\right]-1} \\
& R_{S}=\frac{\frac{N_{S} n k T_{c}}{q} \ln \left(1-\frac{I_{m, r e f}}{I_{s c, r e f}}\right)+V_{o c, r e f}-V_{m, r e f}}{I_{m, r e f}} \\
& n=\frac{q\left(2 V_{m, r e f}-V_{o c, r e f}\right)}{N_{s} k T_{c, r e f}\left[\frac{I_{m, r e f}}{I_{s c, r e f}{ }^{-I} m, r e f}+\ln \left(1-\frac{I_{m, r e f}}{I_{s c, r e f}}\right)\right]} \\
& R_{S h}=\frac{V_{m, r e f}+I_{m, r e f} R_{S}}{I_{L, r e f}-I_{01}\left[\exp \left(q \frac{V_{m, r e f}+I_{m, r e f} R_{S}}{N_{s} k T_{c}}\right)+\exp \left(q \frac{V_{m, r e f}+I_{m, r e f} R_{S}}{N_{s} k T_{c}(p-1)}\right)+2\right]-\frac{P_{\text {max } x \text { ref }}}{V_{m, r e f}}}
\end{aligned}
$$

Yukarıdaki denklemler hesaplandıktan sonra Denklem (39)'da kullanılarak her fotovoltaik hücre gerilimi için bu gerilim değerine karşılık gelen akım değeri hesaplanarak I-V eğrisi elde edilir. Hesaplanan akım ve gerilim değerleri Denklem (4)'te kullanılarak fotovoltaik hücrenin ürettiği maksimum güç değeri hesaplanır. Bulunan değerler doğrultusunda Denklem (13) kullanılarak fotovoltaik hücrenin hesaplanmak istenilen ışınım şiddeti ve sıcaklık değerindeki verimi bulunur. 


\section{I-V EĞRİSi MODEL CÖZÜMLEMELERI}

Fotovoltaik eşdeğer elektrik devre modelleri hesaplanırken kullanılan referans değerler Tablo 2'de verilmiştir. Model hesaplamaları yapılırken Microsoft Visual Basic programlama dili tercih edilmiştir.

Tablo 2. Modellerde Kabul Edilen Referans Değerler

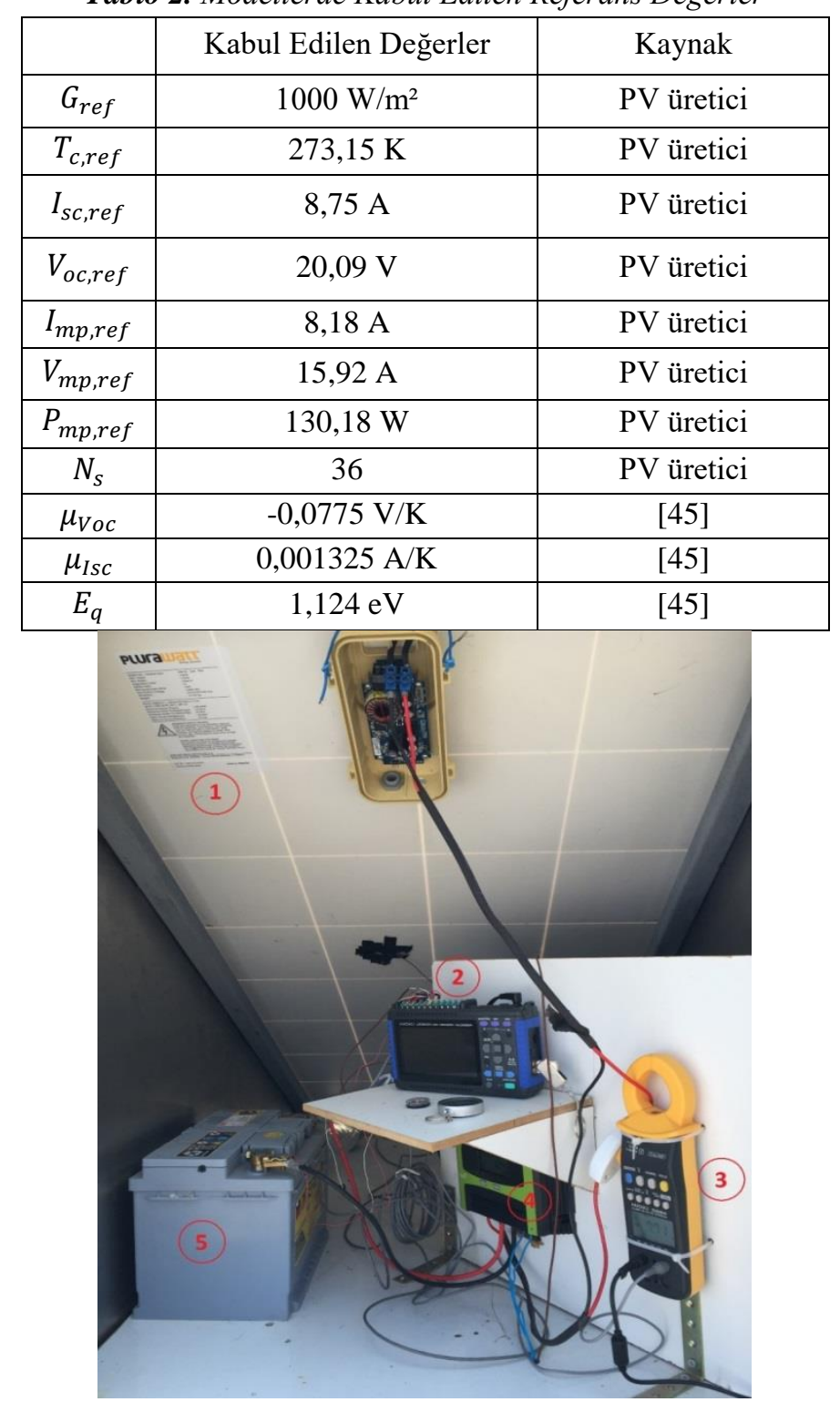

Şekil 11. Mevcut Çalışmada Kullanılan Fotovoltaik Deney Düzeneği

Deneysel analizler Bolu (4042’52.2’K, 31³1'29.8’D) ilinde Abant İzzet Baysal Üniversitesi Gölköy Kampüsü Mühendislik Fakültesinde yapılmıştır. Hazırlanan deney düzeneğinde fotovoltaik panelin yönü, mekanik ve elektronik pusula ile belirlenerek yüzey azimut açısı minimum olacak şekilde konumlandırılmıştır. Fotovoltaik panelin eğim açısı Bolu'nun matematiksel konumu ve dünyanın yıl içerisinde değişen eksen eğikliği göz önünde bulundurularak $34^{\circ}$ olarak belirlenmiştir. Ölçümlerde kullanılan deney düzeneği ve cihazları Şekil 11 ve 12'de gösterilmektedir. 


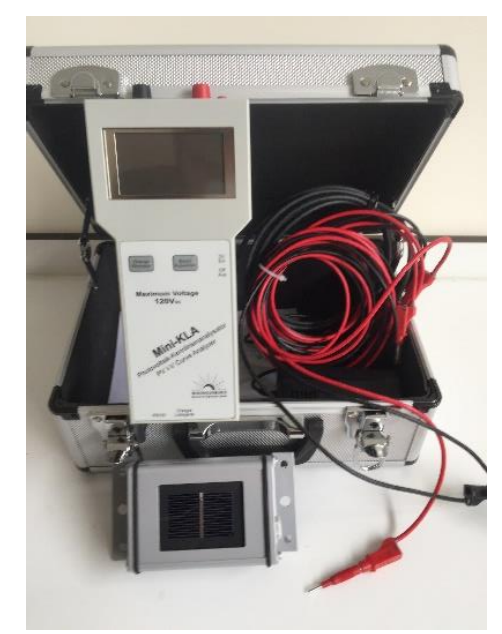

Şekil 12. Mevcut Çalışmada Kullanılan I-V Ĕgrisi Analiz Cihazı

I-V eğrisi analiz cihazı ile farklı günlerde ve günün farklı saatlerinde anlık ölçümler alınarak mümkün olduğunca değişik ışınım şiddeti ve sıcaklık değerleri elde edilmeye çalışılmıştır. Elde edilen bu veriler bilgisayarda kontrol edilerek deney düzeneğinde aktif durumda olan veri kaydedici ile karşlaştırılarak verilerin hassasiyetleri teyit edilmiştir. Elde edilen bu ölçümler Tablo 3'te gösterilmiştir.

Tablo 3. Farklı koşullarda Ölçülen I-V Ĕ̈rilerinin bazı özel değerleri

\begin{tabular}{|c|c|c|c|c|c|c|c|}
\hline $\begin{array}{c}\mathrm{G} \\
\left(\mathrm{W} / \mathrm{m}^{2}\right)\end{array}$ & $\begin{array}{c}\mathrm{T} \\
\left({ }^{\circ} \mathrm{C}\right)\end{array}$ & $\begin{array}{c}I_{s c} \\
(\mathrm{~A})\end{array}$ & $\begin{array}{c}V_{o c} \\
(\mathrm{~V})\end{array}$ & $\begin{array}{c}V_{m} \\
(\mathrm{~V})\end{array}$ & $\begin{array}{c}I_{m} \\
(\mathrm{~A})\end{array}$ & $\begin{array}{c}P_{m} \\
(\mathrm{~W})\end{array}$ & $\begin{array}{c}\text { FF\% } \\
(-)\end{array}$ \\
\hline 1095 & 34 & 9,60 & 19,13 & 13,95 & 8,92 & 124,56 & 67,8 \\
\hline 1066 & 46 & 9,35 & 18,48 & 13,73 & 8,44 & 115,95 & 67,0 \\
\hline 906 & 43 & 7,95 & 18,52 & 14,11 & 7,20 & 101,76 & 69,1 \\
\hline 897 & 29 & 7,85 & 19,47 & 15,00 & 7,22 & 108,31 & 70,8 \\
\hline 806 & 35 & 7,07 & 18,56 & 14,41 & 6,28 & 90,53 & 68,9 \\
\hline 786 & 42 & 6,90 & 18,48 & 14,01 & 6,38 & 89,53 & 70,2 \\
\hline 694 & 37 & 6,09 & 18,64 & 14,59 & 5,57 & 81,38 & 71,6 \\
\hline 670 & 40 & 5,88 & 18,16 & 13,86 & 5,49 & 76,19 & 71,3 \\
\hline 402 & 29 & 3,52 & 18,56 & 15,57 & 3,18 & 49,61 & 75,8 \\
\hline 396 & 24 & 3,46 & 19,11 & 15,59 & 3,24 & 50,54 & 76,2 \\
\hline
\end{tabular}

Bu kısımda, I-V eğrisi analiz cihazı ile elde edilen eğriler Bölüm 3'te anlatılan ve bir önceki kısımda verilen 4 farklı fotovoltaik eşdeğer elektrik devre modelinden elde edilen eğriler ile karşılaştırılmaktadır. Söz konusu modeller farklı 1şınım şiddeti ve sıcaklık koşullarında çözümlenerek ve hem ölçülen veriler ve hem de kendi aralarında olmak üzere karşılaştırmalı olarak incelenmektedir. Modellerden elde edilen sonuçlar istatiksel bir yöntem olan regresyon analizi kullanılarak ölçüm sonuçları ile karşılaştırılmaktadır. Regresyon katsayısı matematiksel olarak şu şekilde ifade edilmektedir [46]:

$R^{2}=1-\frac{\text { Toplam Hataların Karesi }}{\text { Tüm Değerlerin Karesi }}$

Regresyon katsayısı 0 ile 1 arasında değerler almaktadır. Regresyon katsayısının 1'e yaklaşması modelden elde edilen sonuçların ölçülen değerlere yaklaştığını bunun tam tersi olarak 0'a yaklaşması ise modelden elde edilen sonuçların ölçülen değerlerden uzaklaştığı anlamına gelmektedir. 


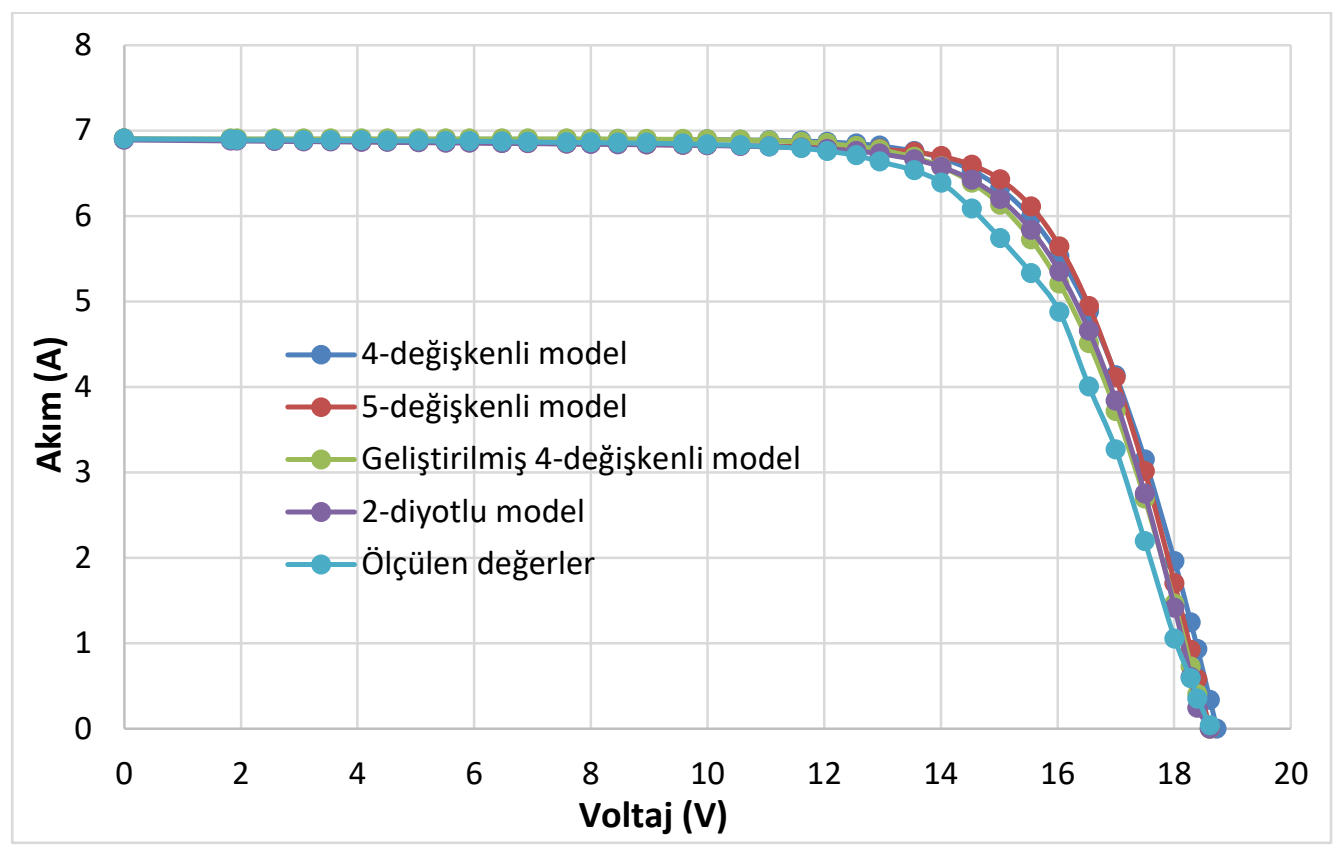

Şekil 13. $786 \mathrm{~W} / \mathrm{m}^{2}$ Işınım Şiddeti ve $42^{\circ} \mathrm{C}$ hücre sıcaklı̆̆ında ölçülen ve modellerden elde edilen I-V Ĕgrileri

Regresyon katsayısı değerlerinin yanı sıra, I-V eğrisi ölçümleri ile fotovoltaik eşdeğer elektrik devresi modelleri üzerinden elde edilen sonuçları karşılaştırmak amacıyla farklı bir istatistiksel yöntem olan kök kareler karesi (Root Mean Squared Error, $R M S E$ ) metodu da hesaplanmış ve doğrulama amacıyla kullanılmıştır. RMSE, hata ortalama büyüklüğünü ölçen, ikici dereceden bir puanlama kuralıdır [47]. $\mathrm{Bu}$ metot uygulanırken eşdeğer elektrik devresi modellemesinden elde edilen sonuç ile I-V eğrisi analiz cihazından elde edilen sonucun farkının karesi alınır. Bu işlem her bir gerilim değeri için yapılarak sonuçların ortalaması alınır. Sonunda ise ortalanan bu değerin karekökü alınır. Bu anlatılan ifade matematiksel olarak altta gösterilmiştir:

$$
R M S E=\sqrt{\frac{\sum_{i=1}^{n}\left(X_{i}-Y_{i}\right)^{2}}{n}}
$$

Yukarıda belirtilen matematiksel ifadede:

$X_{i}=$ Modelden Elde Edilen Sonuç

$Y_{i}=\mathrm{I}-\mathrm{V}$ Eğrisi Analiz Cihazından Elde Edilen Sonuç

değerlerini ifade etmektedir.

RMSE hesaplanırken bulunan sonuçlar 0'dan $\infty$ 'a kadar değişkenlik gösterebilir. Bulunan sonuçların değerlerinin 0'a yakın olması hesaplanan değerler ile istenen değerler arasındaki hata seviyesinin minimum olduğunu göstermektedir.

$786 \mathrm{~W} / \mathrm{m}^{2} 1$ şınım şiddeti ve $42^{\circ} \mathrm{C}$ hücre sıcaklığında elde edilen ölçümler ile model çözümlerinden elde edilen eğriler Şekil 13'te görülmektedir. Modellerden elde edilen sonuçlar ile ölçüm değerleri arasında $R^{2}$ değerleri hesaplandığında 4-değişkenli model için \%98,87, 5-değişkenli model için \%98,14, geliştirilmiş 4-değişkenli model için \%99,51 ve 2-diyotlu model için \%99,05 sonuçları elde edilmiştir. Bu değerlere göre $786 \mathrm{~W} / \mathrm{m}^{2}$ 1şınım şiddeti ve $42^{\circ} \mathrm{C}$ hücre sıcaklığında ölçümlere en yakın sonuç geliştirilmiş 4-değişkenli model tarafından sağlanmaktadır. Yine aynı koşullarda RMSE değerleri 4-değişkenli model için 0,374, 5-değişkenli model için 0,348, geliştirilmiş 4-değişkenli 
model için 0,193 ve 2-diyotlu model için 0,224 olarak hesaplanmıştır. $786 \mathrm{~W} / \mathrm{m}^{2}$ 1şınım şiddeti ve $42^{\circ} \mathrm{C}$ hücre sıcaklığı koşulları için 4-değişkenli modelin minimum hata oranına sahip olduğu görülmektedir. $786 \mathrm{~W} / \mathrm{m}^{2} 1$ şıııım şiddeti ve $42^{\circ} \mathrm{C}$ hücre sıcaklığında alınan ölçümler ile model benzetim yöntemleri üzerinden elde edilen değerler sonucunda güç değerleri hesaplandığında Şekil 14 'te belirtilen güç eğrisi grafiği elde edilmiştir.

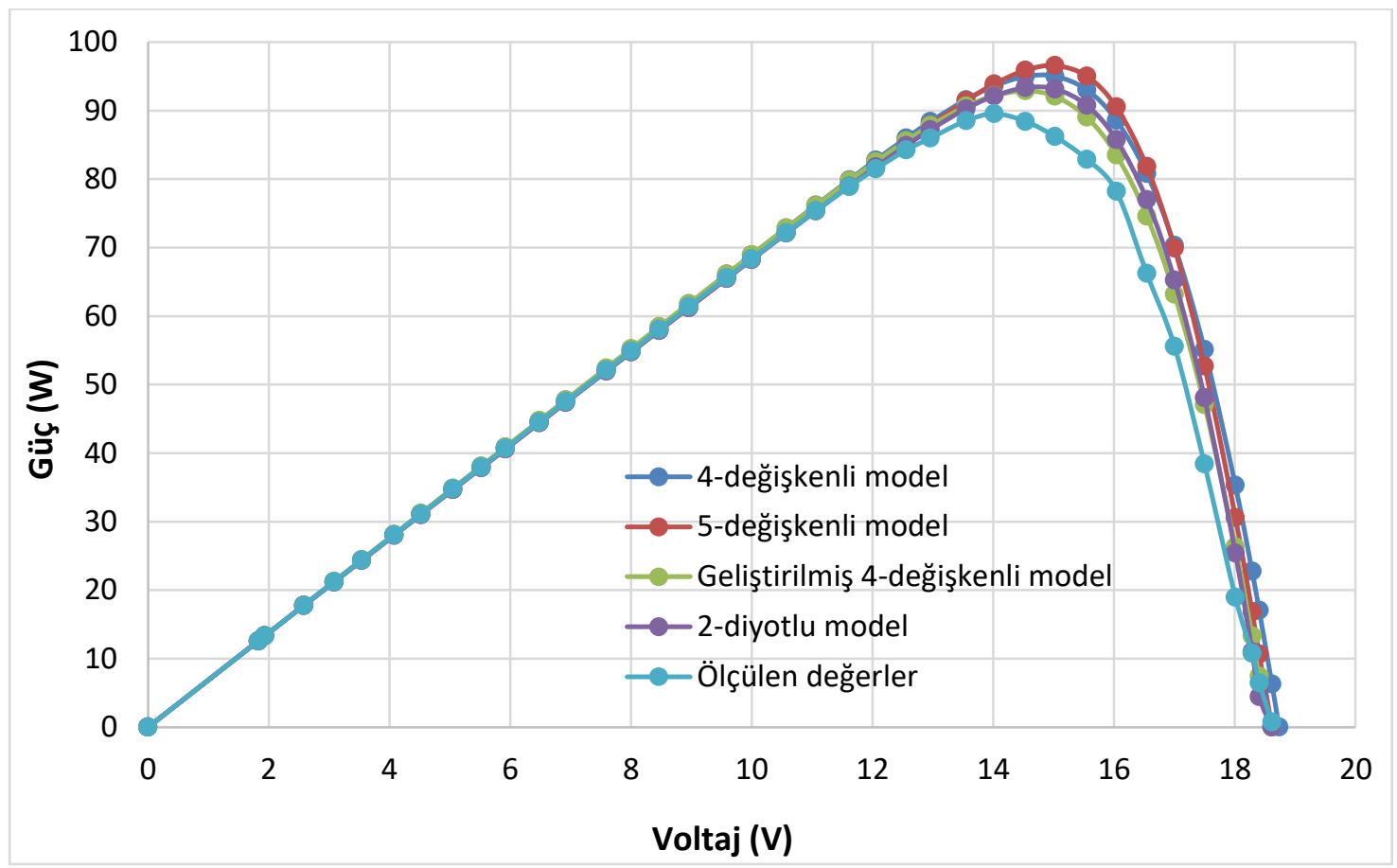

Şekil 14. $786 \mathrm{~W} / \mathrm{m}^{2}$ Işınım Şiddeti ve $42^{\circ} \mathrm{C}$ hücre sıcaklığında ölçülen ve modellerden elde edilen güç $(P-V)$ Ĕgrileri

$1066 \mathrm{~W} / \mathrm{m}^{2}$ 1şınım şiddeti ve $46^{\circ} \mathrm{C}$ hücre sıcaklığında yapılan ölçüm değerlerini karşılaştırmak için bir diğer yüksek 1şınım şiddeti değeri olan $1095 \mathrm{~W} / \mathrm{m}^{2}$ 1şınım şiddetinde fakat bu defa $34^{\circ} \mathrm{C}$ hücre sıcaklığında ölçüm yapılmıştır. Bunun amacı, yüksek ışınım şiddetinde sıcaklığın fotovoltaik panel üzerinden ölçülen ve model benzetim yöntemlerinden hesaplanan akım ve gerilim değerlerine olan etkilerini incelemektir. Yapılan ölçüm sonucunda elde edilen değerler ve model benzetim yöntemleri çözümlenerek ulaşılan akım ve gerilim değerleri Şekil 15'te verilmektedir. 


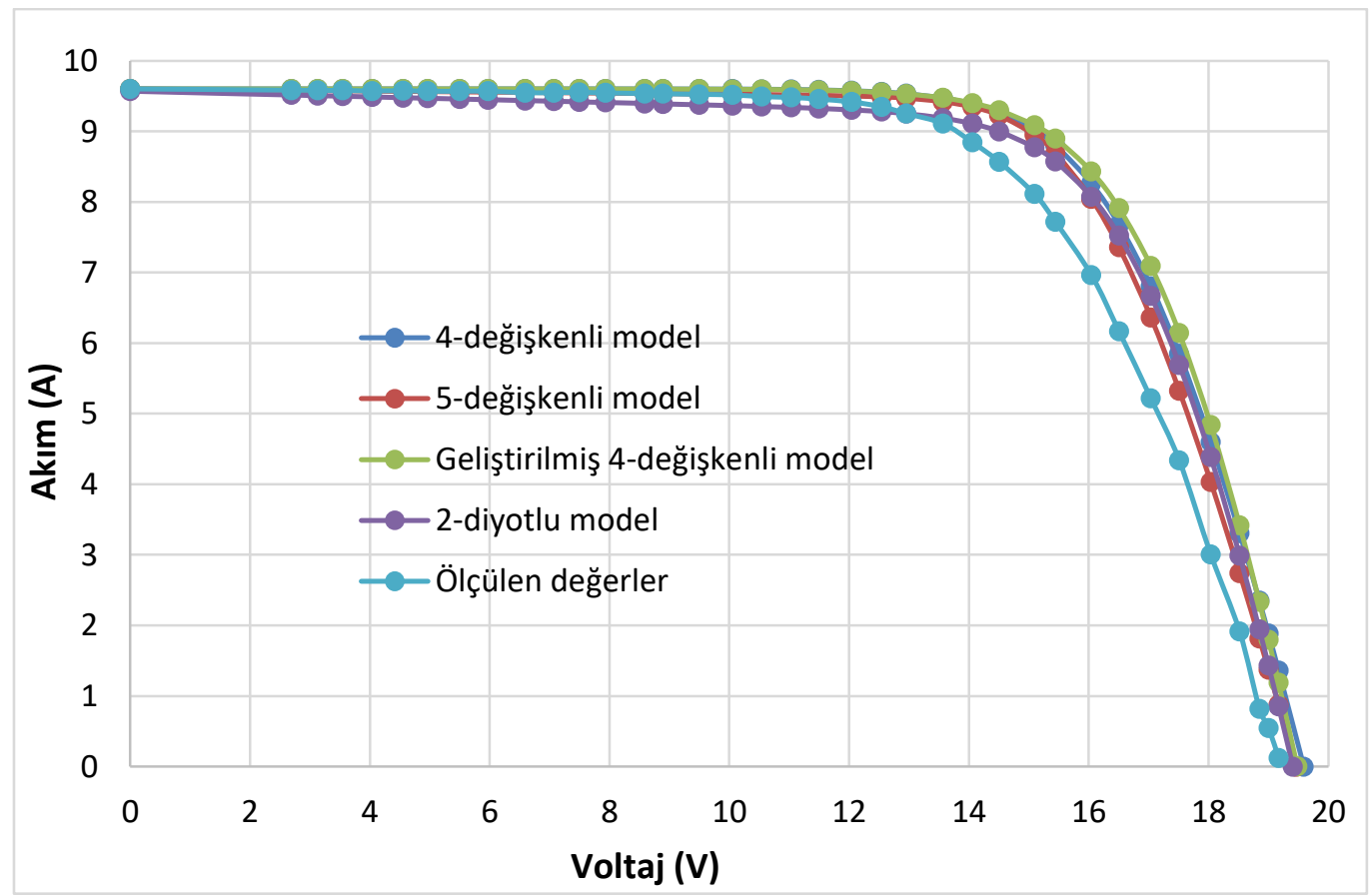

Şekil 15. $1095 \mathrm{~W} / \mathrm{m}^{2}$ Işınım Şiddeti ve $34^{\circ} \mathrm{C}$ hücre sıcaklı̆̆ında ölçülen ve modellerden elde edilen I-V Ĕgrileri

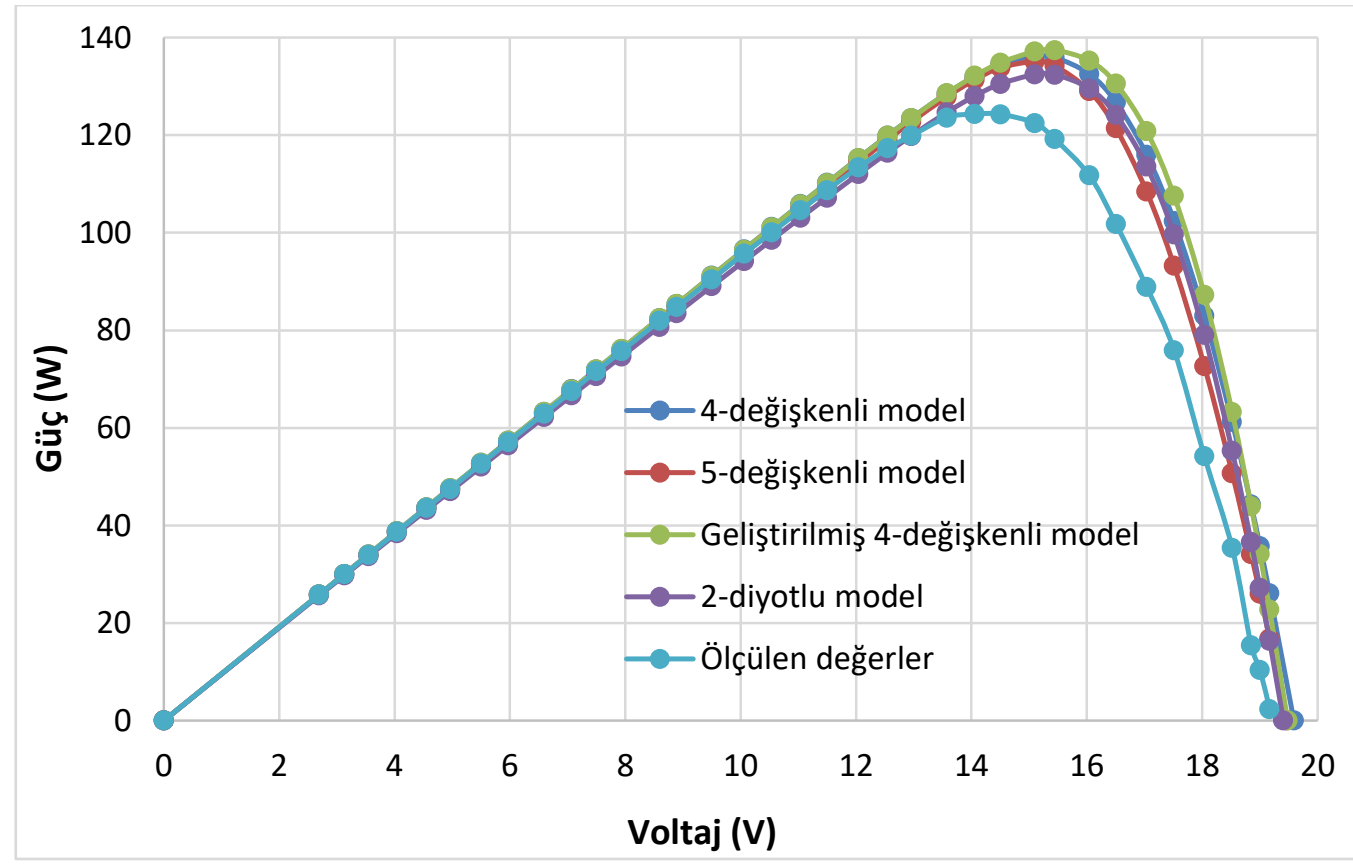

Şekil 16. $1095 \mathrm{~W} / \mathrm{m}^{2}$ Işınım Şiddeti ve $34^{\circ} \mathrm{C}$ hücre sıcaklı̆̆ında ölçülen ve modellerden elde edilen güç $(P-V)$ Eğrileri

Ölçülen ve model benzetimlerinden elde edilen değerleri kıyaslamak için hesaplanan $R^{2}$ değerleri; 4değişkenli model için \%98,45, 5-değişkenli model için \%98,82, geliştirilmiş 4-değişkenli model için \%97,47 ve 2-diyotlu model için \%98,22 olarak elde edilmiştir. Bu 1şınım şiddeti ve sıcaklıkta ölçüm değerlerine en yakın benzetim gösteren modelin 5-değişkenli model olduğu görülmektedir. Aynı koşullarda model benzetimlerindeki hatayı analiz etmek için RMSE değerleri incelendiğinde ise 4değişkenli model için 0,733, 5-değişkenli model için 0,525, geliştirilmiş 4-değişkenli model için 0,797 ve 2-diyotlu model için 0,591 değerleri elde edilmiştir. RMSE değerlerine bakıldığında ise hatanın minimum olduğu benzetim yönteminin 5-değişkenli model olduğu görülmektedir. Söz konusu 1şınım 
şiddeti ve sıcaklıkta hesaplaması ve ölçümü yapılan akım ve gerilim değerinden elde edilen güç eğrisi Şekil 16'da verilmektedir.

\section{MODELLERIN KARSILASTIRMALI ANALIZI}

Ölçülen ve model benzetimlerinden elde edilen değerleri kıyaslamak için hesaplanan $R^{2}$ değerleri; 4değişkenli model için \%98,45, 5-değişkenli model için \%98,82, geliştirilmiş 4-değişkenli model için \%97,47 ve 2-diyotlu model için \%98,22 olarak elde edilmiştir. Bu 1şınım şiddeti ve sıcaklıkta ölçüm değerlerine en yakın benzetim gösteren modelin 5-değişkenli model olduğu görülmektedir. Aynı koşullarda model benzetimlerindeki hatayı analiz etmek için $R M S E$ değerleri incelendiğinde ise 4değişkenli model için 0,733, 5-değişkenli model için 0,525, geliştirilmiş 4-değişkenli model için 0,797 ve 2-diyotlu model için 0,591 değerleri elde edilmiştir. RMSE değerlerine bakıldığında ise hatanın minimum olduğu benzetim yönteminin 5-değişkenli model olduğu görülmektedir. Söz konusu 1şınım şiddeti ve sıcaklıkta hesaplaması ve ölçümü yapılan akım ve gerilim değerinden elde edilen güç eğrisi Şekil 16'da verilmektedir.

$\mathrm{Bu}$ çalışma kapsamında yapılan tüm ölçümler ve bu doğrultuda yapılan modelleme çalışmaları bağlamında elde edilen $R^{2}$ değerleri toplu olarak Tablo 4 'te verilmiştir. Tablo 4 dikkatli bir şekilde incelendiğinde, düşük 1şınım seviyelerinde 4-değişkenli, geliştirilmiş 4-değişkenli ve 2-diyotlu model benzetiminin $R^{2}$ değerlerinin yüksek olduğu görülmektedir. Düşük 1şınım seviyelerinde, 5-değişkenli modelin diğer model benzetimlerine oranla daha düşük $R^{2}$ değerine sahip olduğu görülmektedir. Orta seviyelerdeki 1şınım şiddetlerine bakıldığında, geliştirilmiş 4-değişkenli model benzetiminin $R^{2}$ değerlerinin 1'e daha yakın olduğu görülmektedir. Yüksek 1şınım şiddetlerinde ise 5-değişkenli model benzetiminin diğer model benzetimlerine oranla ölçümlere daha yakınsak değerler verdiği gözlemlenmektedir. Tablo 4'te verilen tüm değerlerin ortalamalarına bakıldığında en yüksek ortalama $R^{2}$ değerinin geliştirilmiş 4-değişkenli model benzetimine ait olduğu görülmektedir.

Tablo 4. Modeller ile Ölçülen I-V eğrileri Arasındaki $\boldsymbol{R}^{2}$ Değerleri

\begin{tabular}{|c|c|c|c|c|c|}
\hline $\begin{array}{c}\mathrm{G} \\
\left(\mathrm{W} / \mathrm{m}^{2}\right)\end{array}$ & $\begin{array}{c}\mathrm{T} \\
\left({ }^{\circ} \mathrm{C}\right)\end{array}$ & $\begin{array}{c}\text { 4-Değişkenli } \\
\text { Model } \\
(\%)\end{array}$ & $\begin{array}{c}\text { 5-Değişkenli Model } \\
(\%)\end{array}$ & $\begin{array}{c}\text { Geliştirilmiş } \\
\text { 4-Değişkenli Model } \\
(\%)\end{array}$ & $\begin{array}{c}\text { 2-Diyotlu Model } \\
(\%)\end{array}$ \\
\hline 396 & 24 & 99,10 & 95,86 & 99,35 & 99,86 \\
\hline 402 & 29 & 99,63 & 97,64 & 99,30 & 99,11 \\
\hline 670 & 40 & 98,79 & 97,30 & 99,69 & 98,93 \\
\hline 694 & 37 & 99,01 & 97,61 & 99,83 & 99,03 \\
\hline 786 & 42 & 98,87 & 98,14 & 99,51 & 99,05 \\
\hline 806 & 35 & 97,45 & 96,29 & 98,34 & 97,72 \\
\hline 897 & 29 & 98,67 & 98,38 & 99,00 & 98,57 \\
\hline 906 & 43 & 98,92 & 98,73 & 98,91 & 98,69 \\
\hline 1066 & 46 & 98,72 & 98,71 & 97,92 & 98,44 \\
\hline 1095 & 34 & 98,45 & 98,82 & 97,47 & 98,22 \\
\hline
\end{tabular}


Tablo 5. Modeller ile Ölçülen I-V ĕgrileri Arasındaki RMSE Değerleri

\begin{tabular}{|c|c|c|c|c|c|}
\hline $\begin{array}{c}\mathrm{G} \\
\left(\mathrm{W} / \mathrm{m}^{2}\right)\end{array}$ & $\begin{array}{c}\mathrm{T} \\
\left({ }^{\circ} \mathrm{C}\right)\end{array}$ & $\begin{array}{c}\text { 4-Değişkenli } \\
\text { Model }\end{array}$ & $\begin{array}{c}\text { 5-Değişkenli } \\
\text { Model }\end{array}$ & $\begin{array}{c}\text { Geliştirilmiş 4- } \\
\text { Değişkenli Model }\end{array}$ & $\begin{array}{c}\text { 2-Diyotlu } \\
\text { Model }\end{array}$ \\
\hline 396 & 24 & 0,192 & 0,363 & 0,093 & 0,220 \\
\hline 402 & 29 & 0,289 & 0,490 & 0,111 & 0,202 \\
\hline 670 & 40 & 0,585 & 0,630 & 0,343 & 0,376 \\
\hline 694 & 37 & 0,304 & 0,360 & 0,113 & 0,161 \\
\hline 786 & 42 & 0,374 & 0,348 & 0,193 & 0,224 \\
\hline 806 & 35 & 0,861 & 0,860 & 0,702 & 0,684 \\
\hline 897 & 29 & 0,436 & 0,396 & 0,347 & 0,306 \\
\hline 906 & 43 & 0,451 & 0,336 & 0,318 & 0,307 \\
\hline 1066 & 46 & 0,552 & 0,314 & 0,513 & 0,385 \\
\hline 1095 & 34 & 0,733 & 0,525 & 0,797 & 0,591 \\
\hline
\end{tabular}

$\mathrm{Bu}$ çalışma kapsamında yapılan tüm ölçümler ve bu doğrultuda yapılan modelleme çalışmaları sonucunda ulaşılan RMSE değerleri toplu olarak Tablo 5'te görülmektedir. RMSE metoduyla hata analizine bakıldığı zaman, düşük ışınım şiddetinde model benzetimlerinin ölçüm değerleri ile farkının göreceli olarak düşük olduğu görülmektedir. Işınım şiddetinin yükselmesiyle birlikte özellikle 2diyotlu ve 5-değişkenli model benzetimlerinin göreceli olarak düşük hata oranlarına yol açtı̆̆ 1 görülmektedir.

\section{SONUC}

Fotovoltaik paneller üzerinde önemli ölçüde etkili olan 1şınım şiddeti ve sıcaklığın yanı sıra, seri devre direnci $\left(R_{S}\right)$, paralel devre direnci $\left(R_{S h}\right)$, kısa devre akımı sıcaklık katsayısı $\left(\mu_{I s c}\right)$ ile açık devre gerilimi sıcaklık katsayısı $\left(\mu_{V o c}\right)$ gibi parametrelerin fotovoltaik eşdeğer elektrik devresi model benzetimleri üzerinde önemli etkiye sahip olduğu bilinmektedir. Bu bağlamda, mevcut çalışmada literatürden alınan ve sabit olarak kabul edilen paralel devre $\left(R_{s h}\right)$ ve seri devre direnç $\left(R_{S}\right)$ değerlerinin mevcut fotovoltaik panel için daha doğru bir şekilde hesaplanmasının elde edilen sonuçların doğruluk derecesini geliştireceği öngörülmektedir. Model benzetimleri ile ölçümler arasında görülen açık devre gerilimindeki farklar bize bu çalışmada kabul edilen $\mu_{V o c}$ değerinin gerçek değerden bir miktar uzak olabileceğini göstermektedir. Aynı şekilde, kısa devre akımında görülen farkların ise $\mu_{I S c}$ değerindeki farklılıktan kaynaklanabileceği göz önüne alınmalıdır. Fotovoltaik hücrelerin karakteristikleri üzerinde önemli etkiye sahip olan bu parametrelerin söz konusu panel için gerçeğe daha yakın değerlerinin tespit edilmesinin, matematiksel modellerin tahmin gücünü önemli ölçüde geliştirebileceği düşünülmektedir.

Buna paralel olarak, yukarıda incelenen modellerin tümünün özellikle belirli voltaj değerleri aralığında ölçülen akım değerlerinden daha yüksek akım değerlerine yol açmaları da yukarıda ifade edildiği üzere mevcut çalışmada kullanılan parametrelerin doğruluk ve hassasiyetleri bağlamında değerlendirilmelidir. Bu doğrultuda, spesifik olarak mevcut çalışma ile ilgili olarak ancak genel olarak da benzer modelleme çalışmaları bağlamında ileride yapılacak çalışmalar için: modellerde kullanılan her bir parametre/değişken ile çıtılar arasında mevcut olan korelasyondan hareketle her bir parametre/değişkenin istatistiksel anlamlılığı yönünde bir öneri ortaya konulabilir. 
TEŞEKKÜR: $\mathrm{Bu}$ araştırma "Bağımsız bir fotovoltaik sistemin nümerik modellenmesi, optimizasyonu ve deneysel validasyonu" başlığı [Proje No: 2017.09.05.1262] ile Bolu Abant İzzet Baysal Üniversitesi tarafından Bilimsel Araştırma Projesi olarak desteklenmiştir.

\section{KAYNAKLAR}

[1] British Petroleum, "BP statistical review of world energy", 2019. [Online]. Available: https://www.bp.com/content/dam/bp/business-sites/en/global/corporate/pdfs/energyeconomics/statistical-review/bp-stats-review-2019-full-report.pdf

[2] International Energy Agency, "Key World Energy Statistics", 2019. [Online]. Available: https://webstore.iea.org/key-world-energy-statistics-2019.

[3] TC Enerji ve Tabii Kaynaklar Bakanlığı, "Dünya ve Türkiye Enerji ve Tabii Kaynaklar Görünümü 2017”, 2017. [Online]. Available: https://www.enerji.gov.tr/tr-TR/Enerji-ve-Tabii-KaynaklarGorunumleri.

[4] Solargis, 2018. [Online]. Available: https://solargis.info/purchase/\#tl=satellite\&ot= CLIMDATA.

[5] M. A. Green, Solar cells: operating principles, technology, and system applications. New York, NY, USA: Prentice Hall, 1981.

[6] İ. Altaş, "Fotovoltaj güneş pilleri: yapısal özellikleri ve karakteristikleri,", Enerji, Elektrik, Elektromekanik-3e, vol. 47, pp. 66-71, 1998.

[7] H. S. Rauschenbach, Solar cell array design handbook: the principles and technology of photovoltaic energy conversion. Netherlands, Springer Science, 2012.

[8] C. Waldauf, P. Schilinsky, J. Hauch and C. J. Brabec, "Material and device concepts for organic photovoltaics: towards competitive efficiencies", Thin Solid Films, vol. 451, pp. 503-507, 2004.

[9] NREL, "Champion photovoltaic module efficiency chart", 2019. [Online]. Available: https://www.nrel.gov/pv/module-efficiency.html, 2019.

[10] V. J. Chin, Z.Salam and K.Ishaque, "Cell modelling and model parameters estimation techniques for photovoltaic simulator application: A review”, Applied Energy, vol. 154, pp. 500-519, 2015.

[11] V. Khanna, B. Das, D. Bisht and P. Singh, "A three diode model for industrial solar cells and estimation of solar cell parameters using PSO algorithm", Renewable Energy, vol. 78, pp. 105-113, 2015.

[12] V. L.Brano, A. Orioli, G. Ciulla and A. Di Gangi, "An improved five-parameter model for photovoltaic modules", Solar Energy Materials and Solar Cells, vol. 94(8), pp. 1358-1370, 2010. 
[13] N. A. Rahim, H. W. Ping and J. Selvaraj, "Photovoltaic module modeling using Simulink/Matlab", Procedia Environmental Sciences, vol. 17, pp. 537-546, 2013.

[14] B. Marion, S. Rummel and A. Anderberg, "Current-voltage curve translation by bilinear interpolation”, Progress in Photovoltaics: Research and Applications, vol. 12(8): 593-607, 2004.

[15] Y. Hishikawa, Y. Imura, T. Oshiro. "Irradiance-dependence and translation of the IV characteristics of crystalline silicon solar cells", presented at the 28th IEEE PV Specialists Conference, Anchorage, Alaska, September 15-20, 2000.

[16] W. De Soto, S. Klein and W. Beckman, "Improvement and validation of a model for photovoltaic array performance", Solar Energy, vol. 80(1) , pp. 78-88, 2006.

[17] A. Toprak, H. Ş. Kılıç, A. Toprak and A. Kepçeoğlu, "Güneş Pilinin Tek Diyot Rs Model Parametrelerinin Hesaplanması ve I-V İle PV Karakteristiklerinin İncelenmesi”, Selçuk Üniversitesi Sosyal ve Teknik Araştırmalar Dergisi vol. 12, pp. 13-22, 2016.

[18] H. R. Ozcalık, S. Yılmaz and E. Kılıc, "Güneş Pilinin Bir Diyotlu Eşdeğer Devre Yardımıyla Matematiksel Modelinin Çıkartılması ve Parametrelerinin İncelenmesi”, Kahramanmaras Sutcu Imam University Journal of Engineering Sciences, vol. 16(1) , pp. 1-10, 2013.

[19] W. Xiao, W. G. Dunford and A. Capel, "A novel modeling method for photovoltaic cells," presented at the 2004 IEEE 35th Annual Power Electronics Specialists Conference, Aachen, Germany, June 20-25, 2004.

[20] N. N. Ulapane, C. H. Dhanapala, S. M. Wickramasinghe, S. G. Abeyratne, N. Rathnayake and P. J. Binduhewa, "Extraction of parameters for simulating photovoltaic panels," presented at the 6th IEEE International Conference on Industrial and Information Systems (ICIIS), Kandy, Sri Lanka, August 16$19,2011$.

[21] R. Chenni, M. Makhlouf, T. Kerbache and A. Bouzid, "A detailed modeling method for photovoltaic cells", Energy, vol. 32(9) , pp. 1724-1730, 2007.

[22] Q. Kou, S. Klein and W. Beckman, "A method for estimating the long-term performance of directcoupled PV pumping systems”, Solar Energy, vol. 64(1-3), pp. 33-40, 1998.

[23] T. Easwarakhanthan, J. Bottin, I. Bouhouch and C. Boutrit, "Nonlinear minimization algorithm for determining the solar cell parameters with microcomputers", International Journal of Solar Energy, vol. 4(1), pp. 1-12, 1986.

[24] A. Ortiz-Conde, Y. Ma, J. Thomson, E. Santos, J. Liou, F. G. Sánchez., M. Lei, J. Finol and P. Layman, "Direct extraction of semiconductor device parameters using lateral optimization method", Solid-State Electronics, vol. 43(4), pp. 845-848, 1999.

[25] P. Saha, S. Kumar, S. K. Nayak and H. S.Sahu, "Parameter estimation of double diode photovoltaic module," presented at the 1st Conference on Power, Dielectric and Energy Management at NERIST (ICPDEN 2015), Arunachal Pradesh, India, January 10-11, 2015. 
[26] K. El-Naggar, M. Al Rashidi, M. Al Hajri and A. Al-Othman, "Simulated annealing algorithm for photovoltaic parameters identification”, Solar Energy, vol. 86(1), pp. 266-274, 2012.

[27] A.Sellami and M. Bouaïcha, "Application of the genetic algorithms for identifying the electrical parameters of PV solar generators" in Solar cells-silicon wafer-based technologies: InTech, L. A. Kosyachenko, 2011.

[28] N. Moldovan, R. Picos and E. Garcia-Moreno, "Parameter extraction of a solar cell compact model usign genetic algorithms,"presented at the Electron Devices, 2009, Santiago de Compastela, Spain, Feb. 11-13, 2009.

[29] W. T. Da Costa, J. F. Fardin, D. S. Simonetti and L. Neto , "Identification of photovoltaic model parameters by differential evolution", presented at the IEEE International Conference on Industrial Technology (ICIT), Vina del Mar, Chile, March 14-17, 2010.

[30] W. Gong and Z. Cai, "Parameter extraction of solar cell models using repaired adaptive differential evolution", Solar Energy, vol. 94, pp. 209-220, 2013.

[31] M. Ye, X. Wang and Y. Xu, "Parameter extraction of solar cells using particle swarm optimization", Journal of Applied Physics, vol. 105(9), pp. 094502, 2009.

[32] L. Sandrolini, M. Artioli and U. Reggiani, "Numerical method for the extraction of photovoltaic module double-diode model parameters through cluster analysis", Applied Energy, vol. 87(2), pp. 442451, 2010.

[33] J. Ma, T. Ting, K. L. Man, N. Zhang, S-U. Guan and P. W.Wong, "Parameter estimation of photovoltaic models via cuckoo search", Journal of Applied Mathematics, vol. 2013, pp. 1-8, 2013.

[34] N. Rajasekar, N. K.Kumar and R. Venugopalan, "Bacterial foraging algorithm based solar PV parameter estimation”, Solar Energy, vol. 97, pp. 255-265, 2013.

[35] A. Askarzadeh and A. Rezazadeh, "Parameter identification for solar cell models using harmony search-based algorithms", Solar Energy, vol. 86(11), pp. 3241-3249, 2012.

[36] M. Al Hajri, K. El-Naggar, M. Al Rashidi and A. Al-Othman, "Optimal extraction of solar cell parameters using pattern search", Renewable energy, vol. 44, pp. 238-245, 2012.

[37] M. Al Rashidi, M. Al Hajri, K. El-Naggar and A. Al-Othman, "A new estimation approach for determining the I-V characteristics of solar cells”, Solar Energy, vol. 85(7), pp. 1543-1550, 2011.

[38] A. Askarzadeh, A.Rezazadeh, "Artificial bee swarm optimization algorithm for parameters identification of solar cell models", Applied energy, vol. 102, pp. 943-949, 2013.

[39] A. Askarzadeh and A. Rezazadeh, "Extraction of maximum power point in solar cells using bird mating optimizer-based parameters identification approach", Solar Energy, vol. 90, pp. 123-133, 2013b. 
[40] A. N. Celik and N. Acikgoz, "Modelling and experimental verification of the operating current of mono-crystalline photovoltaic modules using four-and five-parameter models", Applied energy, vol. 84(1), pp. 1-15, 2007.

[41] M. De Blas, J. Torres, E. Prieto and A. Garcia, "Selecting a suitable model for characterizing photovoltaic devices”, Renewable Energy, vol. 25(3), pp. 371-380, 2002.

[42] R. Khezzar, M. Zereg and A. Khezzar, "Modeling improvement of the four parameter model for photovoltaic modules", Solar Energy, vol. 110, pp. 452-462, 2014.

[43] W. Zhou, H. Yang and Z.Fang, "A novel model for photovoltaic array performance prediction", Applied Energy, vol. 84(12), pp.1187-1198, 2007.

[44] K. Ishaque, Z.Salam and H. Taheri, "Modeling and simulation of photovoltaic (PV) system during partial shading based on a two-diode model", Simulation Modelling Practice and Theory, vol. 19(7), pp. 1613-1626, 2011.

[45] J. A. Duffie and W. A. Beckman. Solar Engineering of Thermal Processes, $4^{\text {th }}$ ed. New York, NY, USA: John Wiley \& Sons. 2013.

[46] D. N. Gujarati, D. C. Porter, Ü Şenesen and Günlük-Şenesen G. Temel Ekonometri, Literatür Yayınc1l1k, 2012.

[47] C. J. Willmott and K. Matsuura, "Advantages of the mean absolute error (MAE) over the root mean square error (RMSE) in assessing average model performance", Climate Research, vol. 30, no.1, pp. 79-82, 2005. 